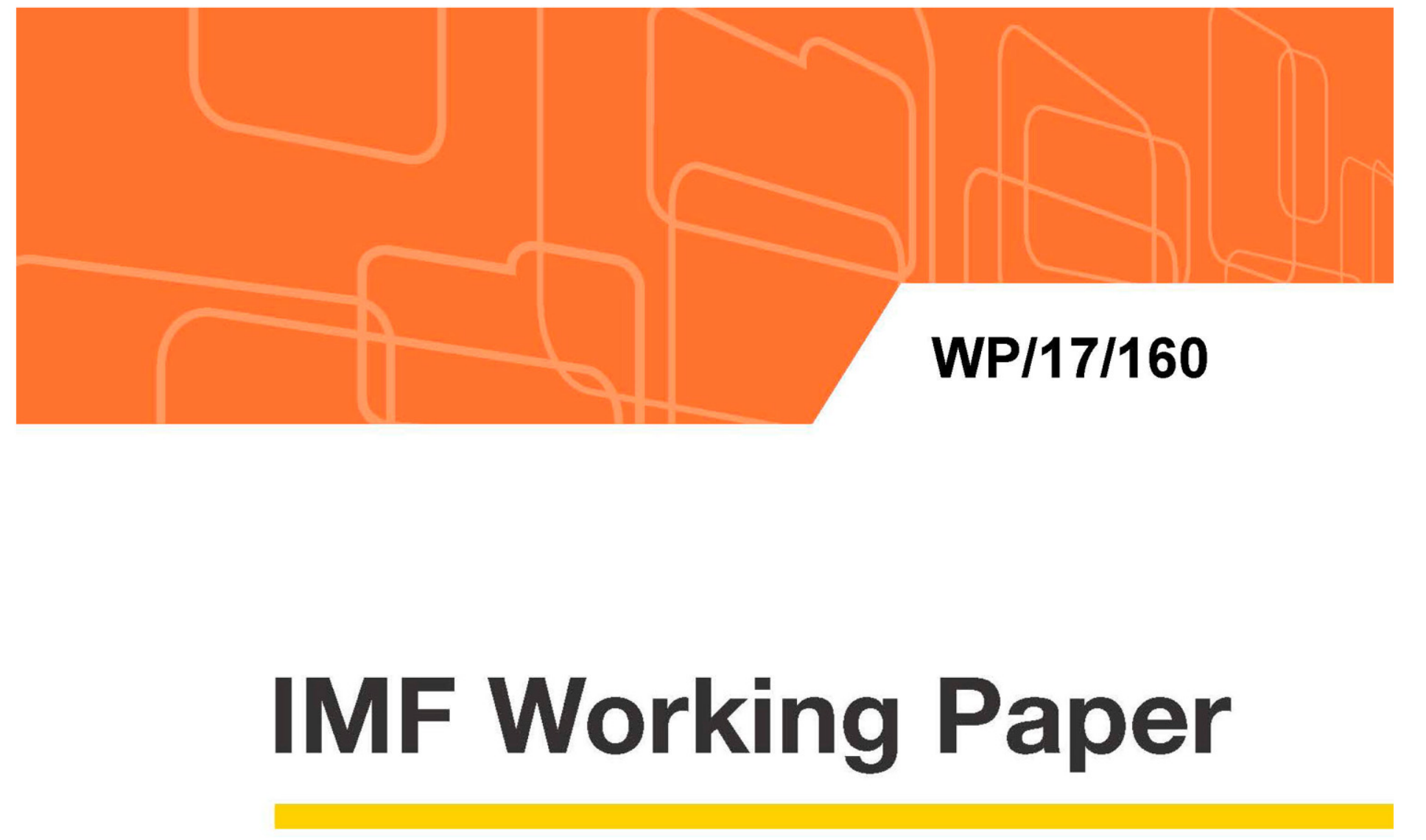

\title{
A Crude Shock: Explaining the Impact of the 2014-16 Oil Price Decline Across Exporters
}

Francesco Grigoli, Alexander Herman, Andrew Swiston

IMF Working Papers describe research in progress by the author(s) and are published to elicit comments and to encourage debate. The views expressed in IMF Working Papers are those of the author(s) and do not necessarily represent the views of the IMF, its Executive Board, or IMF management.

I N T E R N A T I O N A L M O N E T A R Y F U N D 


\title{
WP/17/160
}

\section{IMF Working Paper}

\section{A Crude Shock: Explaining the Impact of the 2014-16 Oil Price Decline Across Exporters}

\author{
Francesco Grigoli, Alexander Herman, Andrew Swiston
}

IMF Working Papers describe research in progress by the author(s) and are published to elicit comments and to encourage debate. The views expressed in IMF Working Papers are those of the author(s) and do not necessarily represent the views of the IMF, its Executive Board, or IMF management.
| N T E R N A T | O N A L
$M O N E T A R Y$
F U N D 


\title{
A Crude Shock: Explaining the Impact of the 2014-16 Oil Price Decline Across Exporters*
}

\author{
Francesco Grigoli $\quad$ Alexander Herman ${ }^{\ddagger} \quad$ Andrew Swiston ${ }^{\S}$
}

\begin{abstract}
The decline in oil prices in 2014-16 was one of the sharpest in history, and put to test the resilience of oil exporters. We examine the degree to which economic fundamentals entering the oil price decline explain the impact on economic growth across oil exporting economies, and derive policy implications as to what factors help to mitigate the negative effects. We find that pre-existing fundamentals account for about half of the cross-country variation in the impact of the shock. Oil exporters that weathered the shock better tended to have a stronger fiscal position, higher foreign currency liquidity buffers, a more diversified export base, a history of price stability, and a more flexible exchange rate regime. Within this group of countries, the impact of the shock is not found to be related to the size of oil exports, or the share of oil in fiscal revenue or economic activity.
\end{abstract}

Keywords: Event study, fundamentals, oil exporters, oil price, transmission of shocks.

JEL Codes: F43, O47, Q43.

*The views expressed in this Working Paper are those of the authors and do not necessarily represent those of the IMF, the U.S. Department of Treasury, the United States Government, or their policies. Working Papers describe research in progress by the authors and are published to elicit comments and to encourage further debate. We thank, without implicating, Rabah Arezki, Yan Carriere-Swallow, Sam Choi, Alfredo Cuevas, Gabriel Di Bella, Metodij Hadzi-Vaskov, Akito Matsumoto, Vina Nguyen, Keyra Primus, Nicolas Magud, Juan Trevino, Bruno Versailles, and the participants to the IMF seminar in June 2017 for their comments and suggestions.

${ }^{\dagger}$ International Monetary Fund; Western Hemisphere Department; fgrigoli@imf.org.

$\ddagger$ U.S. Department of Treasury; Office of International Affairs; alexander.herman@treasury.gov.

§International Monetary Fund; Strategy, Policy and Review Department; aswiston@imf.org.

\section{CInternational Monetary Fund. Not for Redistribution}




\section{Contents}

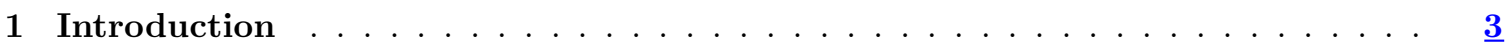

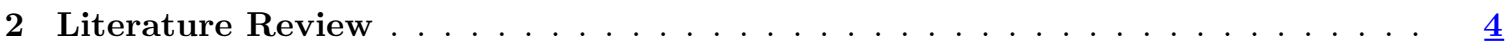

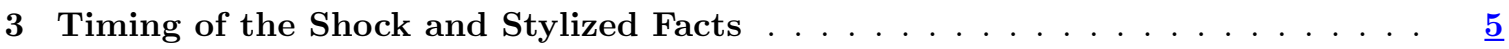

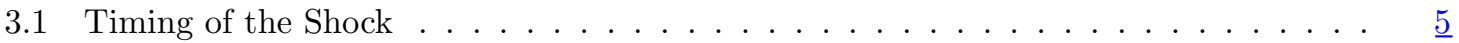

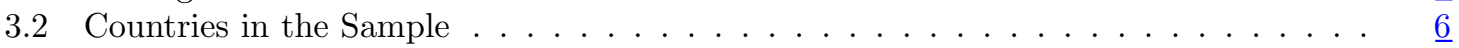

3.3 Assessing the Impact . . . . . . . . . . . . . . . . . . . $\underline{6}$

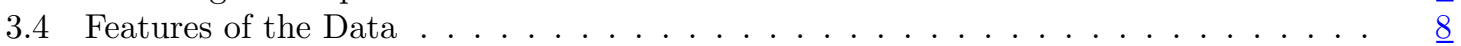

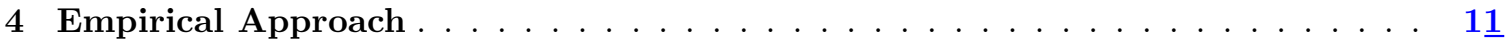

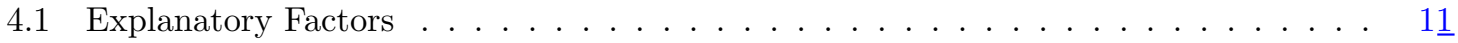

4.2 Regression Framework . . . . . . . . . . . . . . . . . $1 \underline{2}$

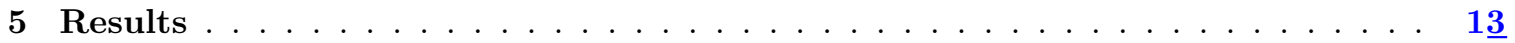

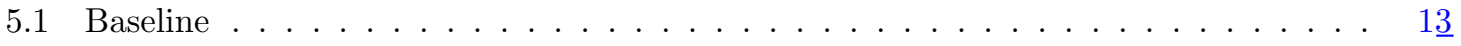

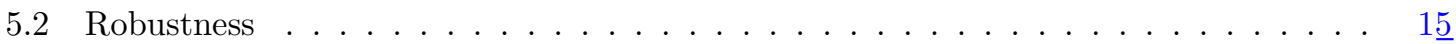

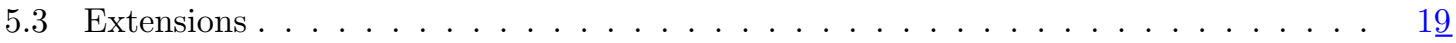

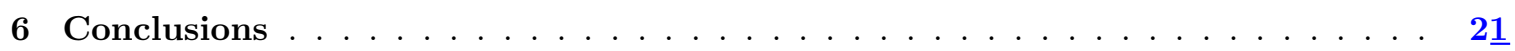

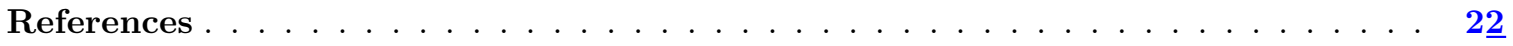

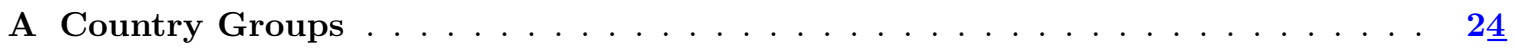

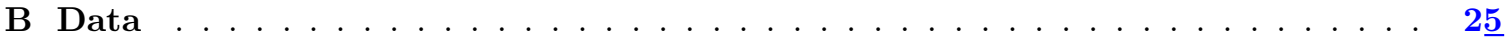

\section{List of Figures}

Page

1 Timing of the Oil Price Shock . . . . . . . . . . . . . . . . . . . . $\underline{7}$

2 Real GDP Growth Forecast Deviations (Percent) . . . . . . . . . . . . . . . $\underline{9}$

3 Oil Dependence .............................. . . . $1 \underline{0}$

4 Oil Shock Impact and Oil Dependence . . . . . . . . . . . . . . . . . . . . . $1 \underline{1}$

5 Country-Specific Contributions to Fitted Values Relative to Sample Mean (Percent) $1 \underline{6}$

\section{List of Tables}

\begin{tabular}{|c|c|c|}
\hline & & Page \\
\hline 1 & Summary Statistics of Real GDP Growth Forecast Deviations . . & $\underline{10}$ \\
\hline 2 & e Specification & $\underline{15}$ \\
\hline 3 & ons with Alternative Fiscal Variables & $\underline{17}$ \\
\hline 4 & Robustness Tests . . & $\underline{18}$ \\
\hline & Exten & $\underline{20}$ \\
\hline 3.1 & Data Sources and Definitions . . . . . . & $\underline{25}$ \\
\hline
\end{tabular}




\section{Introduction}

The macroeconomic fortunes of many countries rise and fall with the price of oil. For many oil exporters, it is the prime source of foreign exchange earnings and fiscal revenue, in addition to comprising a substantial portion of the real economy - both directly via production, and through associated activities such as refining and distribution. Linkages to non-oil activity are also strong, as oil price fluctuations drive changes in national income, fueling consumption and investment. Furthermore, in many oil-dominant economies there are strong linkages to the financial sector as oil companies account for a large share of lending portfolios, creating the potential for oil price swings to affect the health of financial firms, and thus overall credit growth.

These considerations underscore the importance of understanding the transmission from oil price shocks to broader economic outcomes, especially where oil exports are large relative to the economy. To the extent that economic policies influence this transmission, policy priorities can be identified to mitigate the macroeconomic effects of these shocks.

This paper aims to contribute to this understanding by examining the degree to which economic fundamentals entering the 2014-16 oil price decline explain the intensity of its impact on economic growth across oil exporting economies. During this period, prices (on a monthly average basis) fell from over US $\$ 100$ per barrel in July 2014 to less than half that by January 2015. After a brief recovery to about US $\$ 60$ in June 2015, prices halved again to just over $\$ 30$ by February $2016 .{ }^{1}$

This episode was unique among oil price shocks in recent decades, in that the price decline occurred rapidly, was not expected to be quickly reversed, and indeed has turned out to be long lasting. Furthermore, unlike the 2008-09 price decline which occurred alongside the global financial crisis, it did not occur in the midst of other large global shocks that would have had such a sizable impact on economic outcomes in oil exporters. This motivates our empirical approach, which is an event study analysis focusing on macroeconomic outcomes among oil exporters over 2014-16.

This paper finds that to a large extent, the impact of the oil price shock on economic growth is indeed related to economic fundamentals entering the shock. Our results suggest that countries that weathered the shock better tended to have a stronger fiscal position, higher foreign currency liquidity buffers, a more diversified export base, a history of price stability, and a more flexible exchange rate regime. Within the group of oil exporting countries, these factors outweigh any effects coming from the importance of oil, as the impact of the shock is not found to be related to the size of oil exports, or the share of oil in fiscal revenue or economic activity. These findings suggest that policies to reduce vulnerabilities, build buffers, diversify the export base, and strengthen macroeconomic policymaking can play an important role in lowering the exposure of oil exporters to price fluctuations.

The rest of the paper is structured as follows: Section 2 reviews the literature on the macroeconomic effects of oil price shocks, and on event studies of the cross-country effects of the 2008-09 global financial crisis. Section 3 describes the data and some stylized facts, and Section 4 explains the empirical approach taken in the regression analysis. Section 5 presents a number of regressions examining the importance of a wide range of potential explanatory factors, and checks the core findings described above for robustness. Section 6 concludes.

\footnotetext{
${ }^{1}$ Annual average prices provide a relevant reference for our analysis, given its annual frequency. The simple average of Brent, Dubai, and WTI benchmarks in 2014,2015 , and 2016 was US $\$ 96.25$, US $\$ 50.79$, and US $\$ 42.84$, respectively.
} 


\section{Literature Review}

This paper takes as a reference point two strands of the literature - the macroeconomic effects of oil price shocks, and episode studies of the effects of particular shocks across countries. Regarding the macroeconomic impact of oil price shocks, there is abundant evidence on how oil price declines can be highly disruptive for oil exporting countries. This impact can occur via a number of transmission channels. First, a fall in oil prices reduces the real income of oil exporters, which can lower consumption and investment in non-oil sectors (Berument et al., 2010; Cashin et al., 2014).

Fiscal buffers are critical to insulate growth. Due to the often irresistible pressure to scale up public spending during oil price booms, the sudden fall in oil-related revenue can lead to procyclical movements in government spending, jeopardizing economic growth (Van der Ploeg and Poelhekke, 2009; and IMF, 2015b). Furthermore, a major weakness in oil-exporting countries is in building sufficient buffers, which would help weather the impact on growth of sudden declines in oil prices by providing the space to conduct counter-cyclical fiscal policy.

A counter-cyclical monetary policy response can help contain the negative effects of an oil price drop. If the decline in oil prices is persistent enough, and sufficient to result in an undershooting of inflation expectations with respect to the target, a monetary policy reaction may be warranted. In particular, central banks may adopt a looser monetary policy stance to drive inflation expectations back to the target (De Gregorio, 2012). However, the effectiveness of monetary policy is a function of its credibility, and a history of volatile inflation may jeopardize the credibility of the central bank, weakening the effects of its actions. Similarly, if the decline in oil prices occurs at a time in which monetary growth or inflation is already high, the room for easing in response to an oil price shock could be limited.

Oil price declines worsen the current account balance and generate pressure for an exchange rate depreciation (IMF, 2015a). Friedman (1966), Frankel (2005), and Setser (2007) discuss the advantages of running flexible exchange rate regimes as a way to insulate against oil price shocks. In a nutshell, while in a fixed exchange rate regime the adjustment to a drop in oil prices would need to occur through a contraction in the real economy consistent with the pervasiveness of nominal rigidities, a flexible exchange rate would deliver the adjustment through a change in relative prices. Furthermore, for a commodity exporter, exchange rate adjustment may raise fiscal commodity revenue in local currency terms, creating fiscal space. Nonetheless, a sudden and disorderly depreciation can bring about dangerous balance sheet mismatches and a combination of high inflation and low growth. In this context, reserve assets are key. Adequate reserve buffers would help to smooth the transition to a more depreciated currency in economies with flexible exchange rate regimes, and would prevent liquidity crunches in economies with fixed exchange rate regimes or dollarized economies.

An indirect effect of an oil price decline is higher uncertainty. In many economies, investment depends on oil prices, as the latter is a significant determinant of the investment return. When the oil price fall increases uncertainty about its future level, investment falls or is delayed (Bernanke, 1983; Pindyck, 1991; and Kilian, 2014). ${ }^{2}$ More generally, an uncertain macroeconomic environment may lead households and corporations to save the real income from falling oil prices. As a result, consumption (especially of durable goods) may fall (ibid.).

A number of studies have found that the impact of commodity prices on economic activity varies across countries owing to a number of factors, including their dependence on oil (both in terms

\footnotetext{
${ }^{2}$ Anzuini et al. (2015) note that uncertainty about future oil prices may increase precautionary demand of oil.
} 
of fiscal revenue and exports), the macroeconomic policy space before the shock, and fiscal and external buffers, among others. IMF (2015c) finds that swings in the commodity terms of trade have a larger impact on growth in countries with lower levels of financial development, less flexible exchange rates, and more procyclical fiscal policy (where spending responds more strongly to commodity price booms). Similarly, Cespedes and Velasco (2012) find that the response of output to commodity price shocks is buffered in countries with flexible exchange rate regimes and more developed financial markets. Finally, Spatafora and Tytell (2012) find that growth was slower in countries that experienced larger real appreciations during commodity price busts.

The literature on the growth effect of oil price shocks tends to look at a continuum of shocks to oil supply and demand over time and employ a vector autoregressive (VAR) approach to identify these shocks and analyze their impact. ${ }^{3}$

By contrast, studies analyzing the macroeconomic effects of the 2008-09 global financial crisis generally employed an event study methodology using cross-section regressions. ${ }^{4}$ A broad theme that emerged regarding the financial crisis was that its impact on real GDP was larger for countries with higher pre-crisis vulnerabilities. The two main pre-crisis fundamentals that were commonly found to be related to a stronger impact were vulnerability to a sudden stop due to large current account deficits or high levels of short-term external debt (Berkmen et al., 2012; Blanchard et al., 2010; Claesens et al., 2010; Lane and Milesi-Ferretti, 2010; Rose and Spiegel, 2011; Tsangarides, 2012), ${ }^{5}$ and financial system vulnerabilities arising from excessive leverage or credit growth (Berkmen et al., 2012; Claesens et al., 2010; Lane and Milesi-Ferretti, 2010; Rose and Spiegel, 2011).

We take this approach in this paper, as this allows assessment of the effects of a shock across countries, during a unique episode with little precedent in the historical data.

\section{Timing of the Shock and Stylized Facts}

Identifying the timing of the shock and defining how to measure its impact on the economy are two key prerequisites for assessing the factors affecting the transmission of the shock. This section takes up these issues.

\subsection{Timing of the Shock}

Identifying the exact timing of the oil price shock is complicated by the long track record of oil price volatility, as illustrated in the upper-left panel of Figure 1. As an example, the monthly average price peaked at nearly US\$140 per barrel in June 2008, dipped by 70 percent to just over US $\$ 40$ per barrel in January 2009, and then nearly doubled to almost US\$80 per barrel by December of that year.

\footnotetext{
${ }^{3}$ For example, Kilian (2009) introduces a structural VAR that includes global oil prices, production, and economic activity, and analyze the impact of the identified shocks on macroeconomic variables for the U.S. economy. Mohaddes and Pesaran (2015) employ two approaches-a Global VAR and country-specific VAR models-across 27 economies. Jiménez-Rodríguez and Sánchez (2005) also use a VAR framework, incorporating the real effective exchange rate, real wages, inflation, and interest rates for nine OECD economies. Cerdeiro and Plotnikov (2017) build upon Kilian (2009) to analyze the most recent oil price decline relying on country-specific regressions across a sample of 72 countries, as well as estimating counterfactual growth under a no-shock scenario.

${ }^{4}$ Rose and Spiegel (2011) also employ a Multiple Indicator Multiple Cause model.

${ }^{5}$ Some of these studies also found that higher levels of international reserves were associated with a smaller impact of the crisis.
} 
We identify the timing of the shock using two methods: comparing the spot price with historical averages, and examining oil price futures curves. The former method, comparing the spot price with the trailing 24-month average, suggests that the downward break from its previous range began in September 2014, as shown in the upper-right panel of Figure $1 .{ }^{6}$ Regarding the latter method, September 2014 also marks the point at which there was a downward shift in prices across the entire futures curve as indicated by the lower-left panel of Figure 1. This shift deepened in subsequent months. ${ }^{7}$ This shift was to a level below the expected price level in previous months across the curve. These developments suggest that the movement in spot prices at that time was not seen as only reversing a recent increase, which was to a large extent the case for the decline between June and July. Overall, both methods point to September 2014 as the beginning of the shock.

The lower-right panel of Figure 1 places the magnitude of the recent price shock in perspective to other large oil price shocks. The duration of the downward shift in prices has outlasted that of the shock that began in 2008. In that episode prices recovered to near their pre-shock average in the third year after the shock. The shock that began in 1985 represents a cautionary example of the potential duration of shocks, as, other than a brief spike in 1990, prices remained below their real historical average until 2004.

\subsection{Countries in the Sample}

There is a significant degree of heterogeneity in the importance of oil to the economies that export it. Among the 44 countries that export at least 50 thousand barrels of oil per day, oil exports in 2013 ranged from 0.8 to 95 percent of GDP.

To place the impact of the shock in a cross-country perspective while keeping the focus on countries where oil prices were likely one of the main factors in overall economic developments, we focus on a group of 26 countries with substantial oil exports. This includes countries in which oil exports in 2013 exceeded 8 percent of GDP. ${ }^{8}$

Some adjustments are necessary to this group due to data availability and other factors. We exclude South Sudan and Yemen from the core analysis due to the armed conflict in these countries over this period, and Iran and Iraq as their GDP growth performance was strongly affected by increases in oil production not projected as of 2014. Furthermore, we exclude Libya and Syria from all analysis due to data gaps. As robustness checks, we present selected results including Iran, Iraq, South Sudan, and Yemen in the core group of oil-dependent economies; and for all 42 oilexporting countries for which data is available. See Appendix A for a list of countries included in the analysis.

\subsection{Assessing the Impact}

To assess the overall macroeconomic impact of the shock, we examine developments in economic activity as measured by real GDP. Real GDP is generally used in the literature as the variable of

\footnotetext{
${ }^{6}$ Averages over 12 or 36 months yield the same result.

${ }^{7}$ The decline in the futures curve between June and July reversed a short-lived increase that had occurred since March.

${ }^{8}$ Selecting a smaller group of oil exporters following the criteria of Lundgren et al. (2013) and IMF (2015b) (20 percent of fiscal revenue coming from the energy sector, or 20 percent of exports related to oil) does not change the results. Neither does using a metric based on net oil exports rather than gross oil exports.
} 
Figure 1: Timing of the Oil Price Shock

Oil price

(U.S. dollars per barrel, monthly average, WTI)

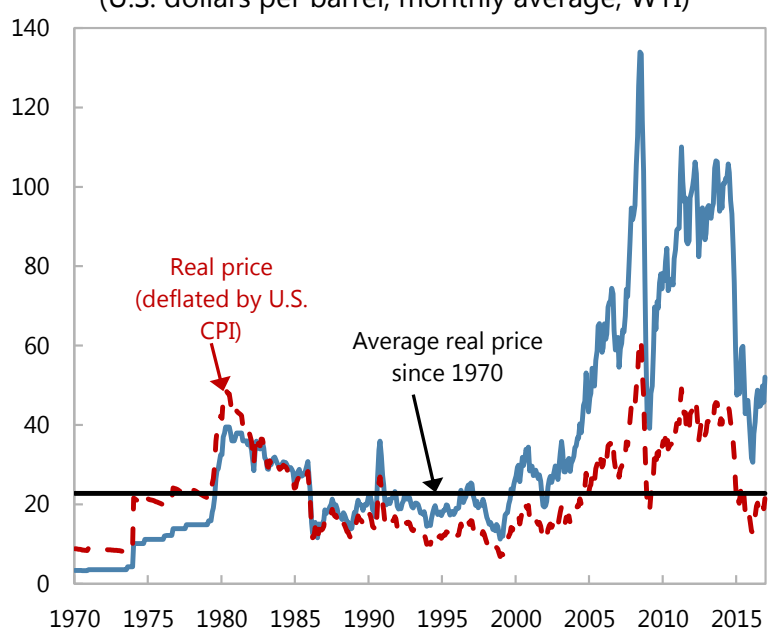

Oil price futures curves

(U.S. dollars per barrel, monthly, eop, WTI)

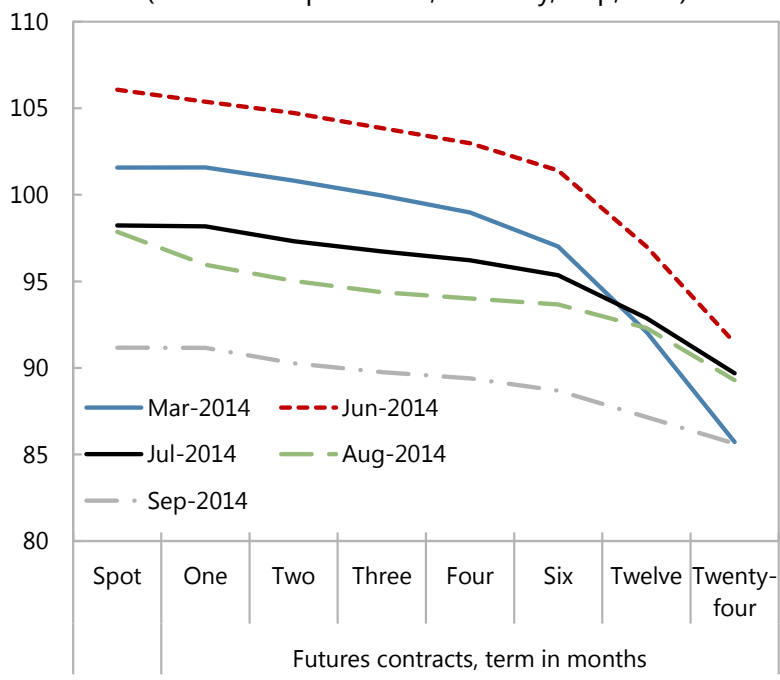

Oil price

(U.S. dollars per barrel, monthly, eop, WTI)

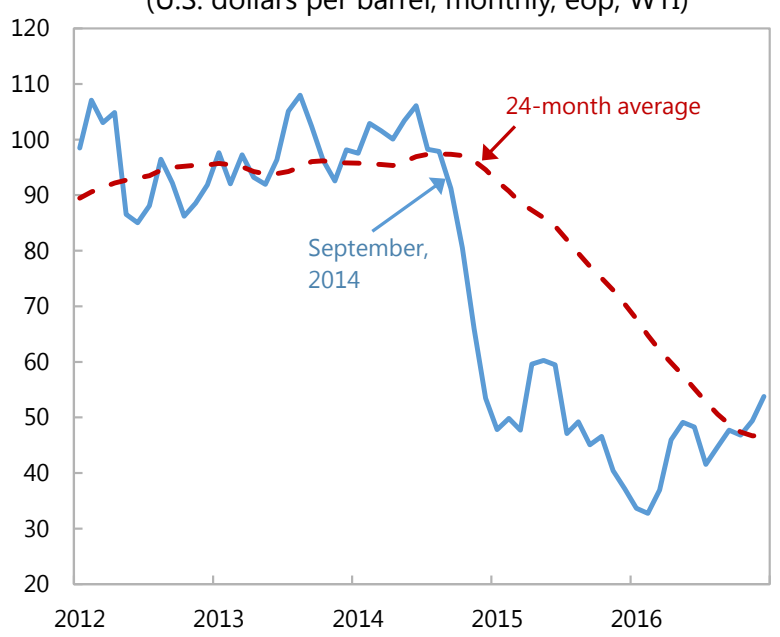

Oil prices during shock episodes (Shock in $\mathrm{t}=1$, avg price in prior 12 months $=100$ )

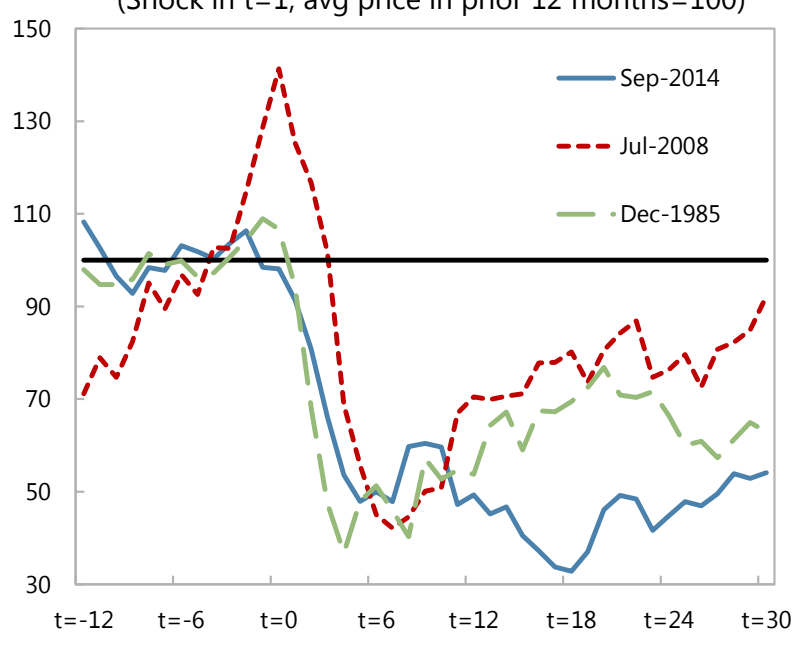

Sources: Haver Analytics; and authors' calculations.

interest given the broad range of transmission channels from oil prices to economic activity in oil exporters. Furthermore, real GDP forecasts are widely available. This helps identify the impact of the shock by separating movements in economic activity that were unexpected at the time of the oil price shock from those that were already incorporated in forecasts - and thus presumably due to other factors. As a robustness check, we present selected results using the slowdown in overall real GDP growth after the shock relative to the period immediately preceding it. We also present results using non-oil real GDP, to gauge the impact of the oil shock on the non-oil sector and as a 
proxy for its effects on domestic consumption and investment. ${ }^{9}$

In order to identify the impact of the shock, different vintages of the IMF's World Economic Outlook (WEO) database are compared. WEO forecasts are produced by IMF country teams in two main rounds each year, with the detailed forecasts typically released in April and October, and finalized based on information available four to six weeks ahead of the release. Given the timing of the WEO exercise relative to that of the shock, the baseline pre-shock forecast vintage is taken as Fall 2014. The Spring 2017 vintage is used to measure the outturn. As such, the dependent variable in our regression analysis is expressed as the cumulative difference in real GDP between the Spring 2017 outturn and the Fall 2014 forecast, thus taking the form:

$$
\delta_{t}^{i}=\left(y_{t}^{i} / y_{2013}^{i}\right)-E_{t}\left(y_{t}^{i} / y_{2013}^{i}\right)
$$

In equation (1), $y_{t}^{i}$ is the level of real GDP of country $i$ at time $t$, which is either 2016 or $2015 .^{10}$ A negative value indicates a stronger impact of the shock, that is, that economic activity was lower than projected.

While the shock began in late 2014 and continued into 2015, oil prices hit a trough in annual average terms in 2016. In addition, the shock would be expected to affect the rest of the economy with a lag. For that reason, the focus is on the cumulative impact through 2016, though we also check robustness of the results when considering the impact through 2015. This approach focuses on the short-run dynamics in response to the shock. While the shock is of a long-run nature, with the passage of time, other factors are more likely to account for differences in growth with respect to previous expectations, making it more difficult to disentangle the effects of the oil price shock.

\subsection{Features of the Data}

Having explained our approach to measuring the impact of the shock on economic activity, we present here a few stylized facts about the features of this data. Figure 2 presents the deviations in real GDP for 2015 and 2016 relative to Fall 2014 forecasts. The degree of the impact varied from minimal (e.g., Cameroon, Algeria, Kuwait, Bahrain, Oman, Malaysia, and Norway) to severe (e.g., Chad, Venezuela, Brunei Darussalam, the Republic of Congo, and Nigeria, all falling short of forecasts by more than 15 percent). The deviations were generally larger in 2016 than in 2015, suggesting that the effects of the fall in oil prices mounted over time.

Table 1 presents some summary statistics of revisions to growth forecasts, which highlight heterogeneity in growth outturns across income levels and exchange rate regimes. Across all oil exporters, the average growth revision measures -7.6 percent, similar to the average revision of 8.2 percent of the core sample. On average, African economies experienced the largest growth revisions at -16.0 percent. Western Hemisphere economies and Middle East and Central Asian economies experienced relatively moderate revisions at -8.1 and -5.9 percent, respectively. Asian and Pacific economies and European economies experienced the mildest revisions at -4.2 percent and -2.0 percent, respectively. Relative to the regional performance, African and Middle Eastern and Central Asian economies were the most varied, as suggested by the high standard deviations.

\footnotetext{
${ }^{9}$ Lack of data availability for a large enough number of countries precludes the analysis of real domestic demand.

${ }^{10}$ This specification comparing the expected cumulative change in real GDP against the outturn allows us to account for data revisions and national accounts rebasing affecting the base year, 2013.
} 
Figure 2: Real GDP Growth Forecast Deviations

(Percent)

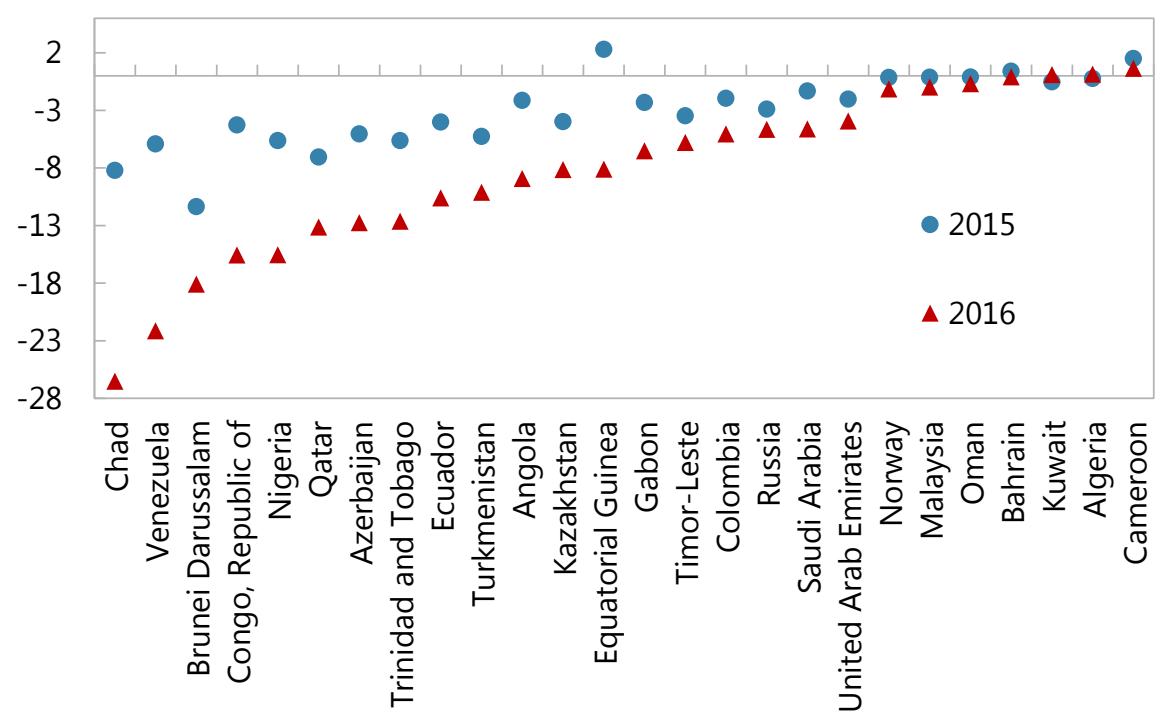

Sources: IMF, WEO; and authors' calculations.

The impact on low-income developing countries (LIDC) ${ }^{11}$ was higher than on advanced economies and emerging markets, with revisions averaging -18.9 percent with a standard deviation of 20.1 percent. Additionally, economies with a fixed exchange rate regime entering the shock experienced larger revisions than those with more flexible regimes; at an average of -10.6 percent, fixed exchange rate economies' revisions were approximately 3 (5) times larger than the average floating (intermediate) exchange rate economy. ${ }^{12}$

Many oil exporters are little diversified and largely dependent on oil, both in terms of exports and fiscal revenue. Figure 3 illustrates oil dependence by showing the share of oil exports and oil revenue in percent of GDP across the countries in the sample. As shown in the left-hand panel, oil exports across the 26 countries shown here range from more than half to less than one tenth of GDP in 2013. This panel also illustrates the fall in average oil exports occasioned by the price decline.

The right-hand panel of Figure 3 shows oil revenue in percent of GDP. Unsurprisingly, oil-related revenue represents an important source of financing for the governments of oil exporters, averaging 22.8 percent of GDP across our sample, but with a large degree of heterogeneity, from more than half of GDP in 2013, to less than 5 percent of GDP. The panel also shows how these shares fell in the aftermath of the oil price shock.

It would be natural to conjecture that the impact of the oil price shock would be related to the degree of oil dependence in a given economy. However, Figure 4 shows that oil exports and fiscal revenue from oil relative to GDP are not correlated with the magnitude of the impact of the

\footnotetext{
${ }^{11}$ LIDCs correspond to all countries that were eligible for IMF concessional financing in 2013 and had a per capita income below USS $\$ 2,390$.

${ }^{12}$ The exchange rate regime is the de facto regime, as assessed in the IMF's Annual Report on Exchange Arrangements and Restrictions (AREAER). The flexible category includes regimes characterized as floating or free floating by the AREAER. The fixed category includes regimes characterized as stabilized arrangement or conventional peg, and all those with a currency board or no separate legal tender. Any other regimes are included in the intermediate category.
} 
Table 1: Summary Statistics of Real GDP Growth Forecast Deviations

\begin{tabular}{|c|c|c|c|c|c|c|}
\hline & Countries & Mean & Median & Std. Dev. & Skewness & Kurtosis \\
\hline \multicolumn{7}{|l|}{ Country groups } \\
\hline All oil exporters & 42 & -7.62 & -4.63 & 11.51 & -2.00 & 7.58 \\
\hline Core sample & 26 & -8.26 & -7.30 & 7.25 & -0.74 & 2.93 \\
\hline \multicolumn{7}{|l|}{ Regions } \\
\hline Africa & 8 & -16.04 & -12.23 & 15.14 & -1.18 & 3.50 \\
\hline Asia and Pacific & 6 & -4.23 & -1.43 & 7.27 & -1.32 & 3.36 \\
\hline Europe & 4 & -1.98 & -1.24 & 1.79 & -1.10 & 2.30 \\
\hline Middle East and Central Asia & 16 & -5.85 & -2.93 & 12.52 & -2.23 & 8.39 \\
\hline Western Hemisphere & 8 & -8.11 & -7.82 & 7.45 & -0.63 & 2.57 \\
\hline \multicolumn{7}{|l|}{ Income groups } \\
\hline Advanced & 5 & -1.33 & -1.14 & 0.54 & -1.04 & 2.75 \\
\hline Emerging & 29 & -5.60 & -5.05 & 6.76 & -0.23 & 3.27 \\
\hline Low income developing & 8 & -18.90 & -15.55 & 20.06 & -0.46 & 1.76 \\
\hline \multicolumn{7}{|l|}{ Exchange rate flexibility } \\
\hline Fixed exchange rate & 26 & -10.61 & -8.50 & 13.62 & -1.39 & 4.87 \\
\hline Intermediate exchange rate & 8 & -2.29 & -1.45 & 3.96 & -0.26 & 1.78 \\
\hline Floating exchange rate & 8 & -3.25 & -1.97 & 3.28 & -1.70 & 4.49 \\
\hline
\end{tabular}

Source: Authors' calculations.

Figure 3: Oil Dependence
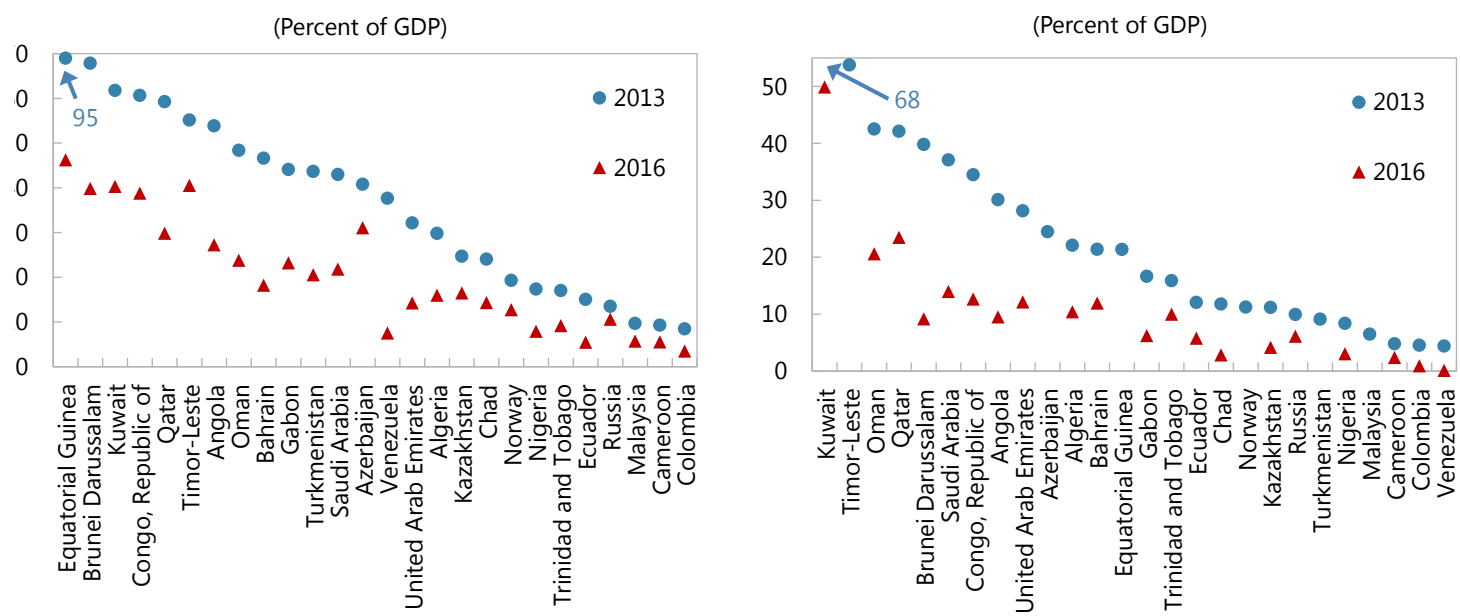

Sources: IMF, WEO; IMF, FAD database; and authors' calculations.

shock on economic activity. ${ }^{13}$ These weak relationships will be confirmed in the regression analysis that follows. Put simply, natural endowments explain little of the variation in the impact of the oil price declines in our sample of oil exporters. This motivates a look at other potential factors, the subject of the next sections.

\footnotetext{
${ }^{13}$ The correlations are similar for oil exports as a share of total exports, oil revenue as a share of total fiscal revenue, and oil GDP as a share of total GDP.
} 
Figure 4: Oil Shock Impact and Oil Dependence
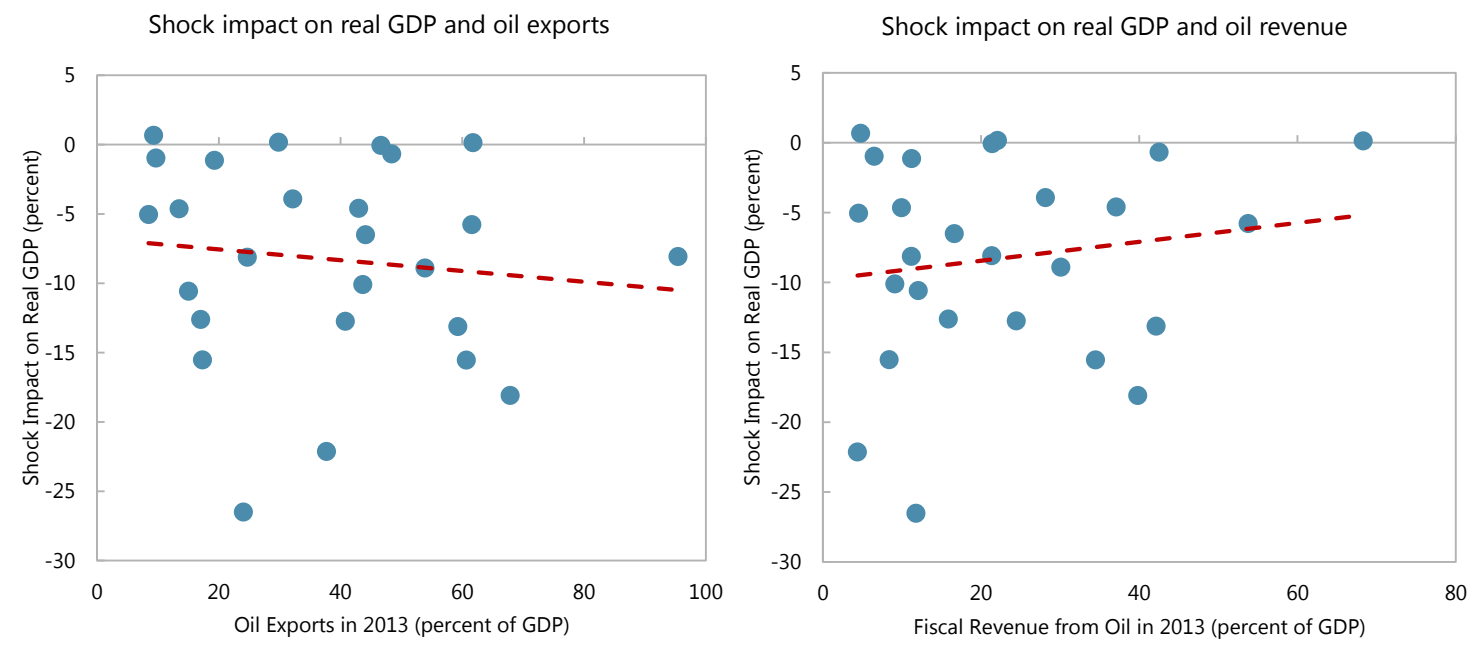

Sources: IMF, WEO; IMF, FAD database; and authors' calculations.

\section{Empirical Approach}

This section discusses the rationale for the choice of explanatory variables and the approach taken in the regression framework in the subsequent section.

\subsection{Explanatory Factors}

We examine a wide range of factors that could potentially explain the cross-country variation in the severity of the impact of the shock, using a number of indicators as proxies for the following factors:

- Macroeconomic policy space: We use several indicators to gauge whether an economy enjoyed space for countercyclical fiscal, monetary, or exchange rate policies to buffer the impact of the shock. Among the fiscal indicators are the overall balance, primary balance, non-oil balance, gap between the primary balance and its debt-stabilizing level, and ratios of net debt to GDP, overall revenue, and non-oil revenue (the latter two as proxies of debt repayment capacity). Indicators of monetary and exchange rate policy space include the output gap as a measure of spare capacity entering the shock, the inflation rate, the historical volatility of inflation (as a measure of the degree to which expectations of price stability were anchored), and the flexibility of the exchange rate regime. ${ }^{14}$

- External factors: We control for revisions to partner country growth and the non-oil terms of trade (both relative to pre-shock forecasts). Other indicators are used as proxies for potential risks to external sustainability, or to measure the availability of buffers that can be

\footnotetext{
${ }^{14}$ As noted above, exchange rate regime flexibility is measured using the assessment of the de facto regime in the IMF's Annual Report on Exchange Arrangements and Exchange Restrictions (AREAER). We construct an indicator that assigns a value of positive one to flexible regimes, negative one to fixed regimes, and zero to intermediate regimes. An alternative variable using the scale of one to ten used in the AREAER yields similar results.
} 
used to smooth adjustment in case of a shock. These include the non-oil current account balance, the level of external liabilities, the level of external assets (both of these covering both the public and private sectors), and the level of reserves (relative to the IMF-standard reserve adequacy metric). ${ }^{15}$

- Oil dependence and economic diversification: As noted above, an economy more dependent on oil for foreign exchange or fiscal revenue, or with a higher share of the oil industry in the overall economy, would be expected to suffer a stronger direct impact. By contrast, a more diversified economy would be expected to weather the shock better to the extent that nonoil sectors are less affected by the shock. The share of oil output in the economy and the ratios of oil exports and oil-related fiscal revenue to GDP are used as indicators of oil dependence. The share of non-oil output and the ratios of non-oil exports and non-oil fiscal revenue to GDP are used as indicators of diversification.

- Structural flexibility: The ability for an economy to redeploy resources across sectors in response to a shock would be expected to contribute to resilience. Indicators of the business environment and governance constructed by the World Bank are used as proxies. A deeper financial system could also help agents within the economy smooth consumption and investment in response to the shock. The ratios of private credit and broad money to GDP are used as indicators of financial development, as is a broader index of financial development constructed in Svirydzenka (2016).

\subsection{Regression Framework}

The econometric specification takes the following form:

$$
\delta_{t}^{i}=\alpha+\beta_{k} X_{k, 2013}^{i}+\epsilon^{i}
$$

where $\alpha$ is the constant term, $X^{i}$ is a set of $k$ explanatory variables as of 2013-immediately before the shock, $\beta$ are the respective coefficients, and $\epsilon^{i}$ is the error term.

Two aspects of this specification bear further discussion-identifying the role of the policy response, and the choice to examine only the 2014-16 episode and not other oil price shocks. Indicators of the policy response are particularly susceptible to endogeneity. This can be illustrated by decomposing the explanatory variables in equation (2) into those measuring the policy response and those measuring other aspects that affect the impact of the shock, as in the following equation:

$$
\delta_{t}^{i}=\alpha+\beta_{k} X_{k, 2013}^{i}+\gamma_{k} P_{k,(2014 ; t)}^{i}+\epsilon^{i}
$$

In this equation, $X^{i}$ contains only non-policy variables before the shock, with policy variables measured by $P^{i}$ during the duration of the shock (2014 till $t$ ). Given that a positive value of $\delta_{t}^{i}$ signifies a lower impact of the shock, assume the explanatory variables are expressed so that a positive value implies stronger fundamentals (for the non-policy variables) or an easing of policy (for the policy variables). A policy easing should be expected to improve outcomes ( $\operatorname{raising} \delta_{t}^{i}$ ),

\footnotetext{
${ }^{15}$ Lack of data availability on maturing external obligations prevented using indicators on short-term external liabilities coming due. See Appendix B for further details about how the metric is constructed.
} 
all else equal. However, the degree of easing is likely to be higher in response to a worsening economic situation (where $\delta_{t}^{i}$ is falling). This implies that the signs on $\gamma_{k}$ are likely to be biased toward zero.

The magnitude of the policy response will also depend on the available policy space, embodied in fundamentals entering the shock, proxied by the elements of $X^{i}$. However, these fundamentals typically have both an indirect effect through policy space and a direct effect, for example through bolstering confidence and thus limiting outflows of foreign investment in response to the shock, preventing them from serving as valid instruments that could be used to isolate the component of the policy response that was not related to the intensity of the shock. For this reason, as in Blanchard et al. (2010), Lane and Milesi-Ferretti (2010), and Berkmen et al. (2012) for the Global Financial Crisis, our empirical analysis focuses on each country's fundamentals at the time of the shock-in this case, 2013 values-as explanatory variables.

A panel approach covering multiple historical episodes could potentially help shed light on the factors underlying the macroeconomic effects of oil price shocks. However, as noted above, the 2014-16 oil price shock is one of only three such declines over the last few decades. The effects of the price decline during 2008-09 were experienced at the same time as those of the global financial crisis (and likely driven to a large extent by it). This would confound attempts to isolate the impact of lower prices on oil exporters during that episode. Furthermore, given that there was a somewhat rapid partial recovery in prices, and the macroeconomic effects of oil price shocks are likely to differ based on how long they last, it is questionable whether such a direct comparison between the two episodes would be appropriate. The 1985-86 price decline was a more comparable episode, but it is not possible to assess its impact in the same way because data is not available for a sufficient number of countries.

For these reasons, we employ an event-study approach using cross-section regressions. As noted above, this is in line with the literature analyzing the determinants of the impact of the 2008-09 Global Financial Crisis on economic activity.

\section{Results}

In this section we turn to the econometric evidence. First, we present the results from the estimation of a baseline specification including only significant variables. Second, we show the results of tests aimed at ensuring the robustness of the findings of the baseline specification. And third, we present some extensions to the baseline results by testing some additional variables for significance.

\subsection{Baseline}

As discussed in Section 4, we examine a wide range of explanatory variables from the following categories: macroeconomic policy space, external factors, oil dependence and economic diversification, and structural flexibility. Given the construction of the dependent variable, a positive sign on a regressor means it facilitates better economic performance, as reflected in a more positive deviation from the forecast. Table 2 presents the results for the core sample, the core sample plus other heavily oil-dependent economies, and for the broader category of oil exporters.

In the baseline specification, shown in column 1, we find five variables that are significantly re- 
lated to the severity of the impact of the shock. ${ }^{16}$ Among those measuring the macroeconomic policy space, a more flexible exchange rate regime and higher reserve adequacy soften the magnitude of the shock's impact. The coefficient on the exchange rate regime signifies that, all else equal, growth outturns in countries with floating exchange rates were 2.9 percentage points (pp) higher than those with intermediate regimes and nearly 6 pp higher than those with stabilized or fixed regimes. A one pp increase in reserve adequacy as a percent of the IMF metric yields a statistically significant $0.007 \mathrm{pp}$ impact. This implies that the growth outturn for the country in the third quartile, with a reserve adequacy ratio of 197 , was $0.8 \mathrm{pp}$ higher than for a country in the first quartile, with an adequacy ratio of 83 . The ratio of net government debt to revenue is also statistically significant. The growth outturn for a country in the third quartile, with net debt equivalent to 102 percent of fiscal revenue, was $0.5 \mathrm{pp}$ lower than that of a country in the first quartile, with net debt of -154 percent of revenue (i.e., assets greater than debt). For inflation volatility, the coefficient implies a growth outturn 1.9 pp higher for countries in the third quartile than those in the first quartile (standard deviations of 0.7 and 1.9, respectively). Finally, countries with higher non-oil exports as a share of GDP were less negatively affected by the shock. The growth outturn was 1.5pp higher for a country in the third quartile of the sample, with non-oil exports of 17.8 percent of GDP, than for a country in the first quartile, with non-oil exports of 7.7 percent of GDP.

For the core sample, the five variables significant in the preferred specification explain almost 60 percent of the cross-country variation in deviations of real GDP from forecasts in response to the decline in oil prices. The same variables were still significant when the sample was expanded to four oil exporters that experienced fluctuations in oil production and overall economic activity due to severe armed conflict and other exogenous factors (column 2), as well as to a range of another 12 less oil-dependent countries (column 3). While, as expected, the specification explains a lower fraction of growth developments in those groups of countries, point estimates are relatively similar across samples. ${ }^{17}$

Figure 5 shows the contribution of each variable to the fitted value for each country relative to the sample mean in the baseline specification for the core sample. This illustrates how the roles of the explanatory variables in explaining the growth outturn differ across countries, and also allows an examination of how accurate the specification is in explaining the outturn for any given country.

Given the difficulty in summarizing the degree of available fiscal space in a single variable, we run a wide array of specifications for the core sample using a number of variables. We report the results of the estimations in Table 3 replacing net government debt in percent of revenue with the same variable normalized by GDP (column 1) and by non-oil revenue (column 2), the primary balance normalized by GDP (column 3) and by revenue (column 4), and the overall balance in percent of GDP (column 5).

The results of Table 3 corroborate our finding that countries with more fiscal space are less susceptible to the contractionary effects of falling oil prices. All the variables mentioned above return results with the expected sign, i.e. negative for debt variables and positive for primary and overall balance, and many of them return significant coefficients. ${ }^{18}$ In particular, net government debt in

\footnotetext{
${ }^{16}$ While multicollinearity could pose an issue, in this sample it does not appear to be a significant problem, as tests for variance inflation factors and condition indexes returned values below 10, suggesting a low degree of multicollinearity. In addition, variables that turned out significant in univariate regressions were added to progressively larger groups of variables to arrive at the baseline specification while ensuring that no variable that was robustly significant was excluded.

${ }^{17}$ The relatively small sample size prevents exploring differential effects of the baseline regressors across regions and income groups. To study fixed regional or income group fixed effects, however, we include regional or income group dummies, but coefficients turn out insignificant.

${ }^{18}$ While we are aware of the endogeneity bias, we attempt the inclusion of indicators of the fiscal policy response
} 
Table 2: Baseline Specification

\begin{tabular}{|c|c|c|c|}
\hline & \multicolumn{3}{|c|}{$\begin{array}{c}\text { Dependent variable: } \\
\text { Percent deviation of actual } 2016 \\
\text { real GDP growth from Fall } 2014 \\
\text { WEO forecast }\end{array}$} \\
\hline & $\begin{array}{c}(1) \\
\text { Core } \\
\text { sample } \\
\end{array}$ & $\begin{array}{c}\text { (2) } \\
\text { Heavily oil } \\
\text { dependent } \\
\end{array}$ & $\begin{array}{c}(3) \\
\text { All oil } \\
\text { exporters } \\
\end{array}$ \\
\hline Exchange rate flexibility & $\begin{array}{c}2.948^{* * *} \\
(0.975)\end{array}$ & $\begin{array}{l}3.896^{* *} \\
(1.647)\end{array}$ & $\begin{array}{l}3.332^{* *} \\
(1.464)\end{array}$ \\
\hline Non-oil exports (percent of GDP) & $\begin{array}{l}0.147^{* *} \\
(0.056)\end{array}$ & $\begin{array}{l}0.128^{*} \\
(0.070)\end{array}$ & $\begin{array}{l}0.160^{* *} \\
(0.064)\end{array}$ \\
\hline Reserve adequacy (percent of IMF metric) & $\begin{array}{c}0.007^{* * *} \\
(0.001)\end{array}$ & $\begin{array}{c}0.010^{* * *} \\
(0.003)\end{array}$ & $\begin{array}{l}0.007^{* *} \\
(0.003)\end{array}$ \\
\hline Inflation volatility (percent) & $\begin{array}{c}-1.614^{* *} \\
(0.666)\end{array}$ & $\begin{array}{c}-1.481^{* * *} \\
(0.161)\end{array}$ & $\begin{array}{c}-1.167^{* * *} \\
(0.331)\end{array}$ \\
\hline Net government debt (percent of revenue) & $\begin{array}{c}-0.002^{* * *} \\
(0.000)\end{array}$ & $\begin{array}{c}-0.002^{* * *} \\
(0.001)\end{array}$ & $\begin{array}{l}-0.001^{*} \\
(0.001)\end{array}$ \\
\hline Constant & $\begin{array}{c}-8.271^{* * *} \\
(1.965)\end{array}$ & $\begin{array}{c}-7.973^{\star \star *} \\
(2.366)\end{array}$ & $\begin{array}{c}-7.752^{* * *} \\
(2.501)\end{array}$ \\
\hline $\begin{array}{l}\text { Observations } \\
\text { R-squared }\end{array}$ & $\begin{array}{c}26 \\
0.581\end{array}$ & $\begin{array}{c}30 \\
0.546\end{array}$ & $\begin{array}{c}42 \\
0.420\end{array}$ \\
\hline
\end{tabular}

Source: Authors' calculations.

Notes: Heteroskedasticity robust standard errors in parentheses; ${ }^{* *},{ }^{* *}$, and ${ }^{*}$ next to a number indicate statistical significance at 1,5 , and 10 percent, respectively.

percent of GDP and percent of non-oil revenue, as well as the primary balance in percent of nonoil revenue yield statistically significant results. ${ }^{19}$ These effects could come through higher discretionary fiscal policy undertaken to buffer the effects of the shock, or less pressure on financing conditions due to higher confidence in fiscal sustainability. ${ }^{20}$ These results also underline the robustness of the other explanatory variables, as they all remain significant and present the expected sign.

\subsection{Robustness}

We now turn to examine the robustness of the baseline specification. Table 4 reports the results of several alternative specifications for the three sample groups. In columns 1 to 3 we maintain all the baseline explanatory variables but we replace the dependent variable with the "slowdown" in real GDP growth calculated as the difference between the compound growth rate in 2015-16 and that over 2011-14. Similarly, in columns 4 to 6 we use the same slowdown variable over the

(i.e., the change in the non-oil overall or primary balance, or change in primary expenditure), but the coefficients turn out insignificant. In these additional regressions, we do not adjust for the effects of the shock on non-oil revenue or on expenditure via automatic stabilizers as we are interested in the overall effect.

${ }^{19}$ We also attempt the inclusion of the difference between the actual primary balance before the oil shock and the debt-stabilizing primary balance, but the coefficient is not significant.

${ }^{20}$ Directly testing whether discretionary fiscal measures helped offset the impact of the oil price decline would help assess the relative importance of these two channels, but data on structural balances were not available for a sufficient number of countries. 
Figure 5: Country-Specific Contributions to Fitted Values Relative to Sample Mean

(Percent)

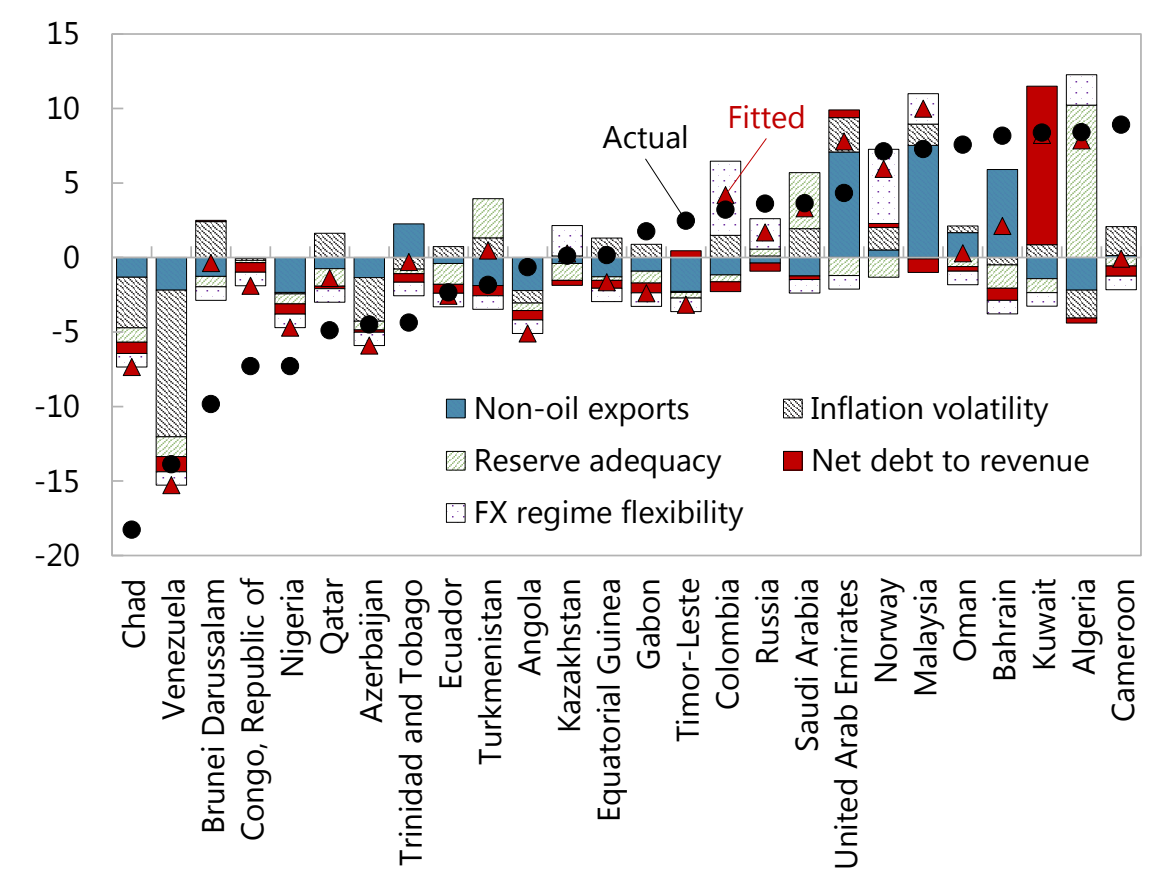

Source: Authors' calculations.

Notes: The contribution of the constant term is excluded from the figure.

same period as in columns 1 to 3 , but this time for non-oil real GDP. ${ }^{21}$ In columns 7 to 9 , we restore the baseline dependent variable, but we use the real GDP growth forecast of Spring 2014 for its construction. ${ }^{22}$ Finally, in columns 10 to 12 and columns 13 to 15, we replace the explanatory variables (with the exception of the exchange rate regime flexibility) with their 2011-13 and 201213 averages, respectively.

The main results continue to hold when using the slowdown in real GDP growth as the dependent variable. However, the exchange rate regime flexibility loses statistical significance in the core sample and the sign on inflation volatility switches for the broader samples. This suggests that the method of identifying the growth impact of the shock is not driving the results.

Similarly, the results generally hold when using the slowdown in non-oil real GDP growth, with the exception that inflation volatility loses significance. This provides evidence of an impact beyond the oil sector alone, to the domestic economy more broadly, including consumption and nonoil investment.

Changing the timing of the measurement of the real GDP growth forecast to the Spring 2014 vintage does not affect the main conclusions derived from the results of the baseline specification. As shown in columns 7 to 9 , all variables are still significant and with the expected sign, with the exception of net government debt, which loses significance for the broad group of oil exporters. Analogously, replacing the explanatory variables with their average values instead of the 2013

\footnotetext{
${ }^{21}$ Forecasts for non-oil real GDP are not available for a sufficient number of countries to assess the difference between the actual and forecast as the dependent variable.

${ }^{22}$ Also, instead of using the 2013 value for non-oil exports measured in Fall 2014, we use the value measured in Spring 2014.
} 
Table 3: Specifications with Alternative Fiscal Variables

\begin{tabular}{|c|c|c|c|c|c|}
\hline & \multicolumn{5}{|c|}{$\begin{array}{c}\text { Dependent variable: } \\
\text { Percent deviation of actual } 2016 \text { real GDP growth from } \\
\text { Fall } 2014 \text { WEO forecast }\end{array}$} \\
\hline & $\begin{array}{c}\text { (1) } \\
\text { Core } \\
\text { sample }\end{array}$ & $\begin{array}{c}\text { (2) } \\
\text { Core } \\
\text { sample } \\
\end{array}$ & $\begin{array}{c}\text { (3) } \\
\text { Core } \\
\text { sample } \\
\end{array}$ & $\begin{array}{c}\text { (4) } \\
\text { Core } \\
\text { sample } \\
\end{array}$ & $\begin{array}{c}(5) \\
\text { Core } \\
\text { sample }\end{array}$ \\
\hline Exchange rate flexibility & $\begin{array}{c}2.951^{* * *} \\
(0.984)\end{array}$ & $\begin{array}{l}3.128^{* * *} \\
(1.044)\end{array}$ & $\begin{array}{l}2.783^{* *} \\
(0.994)\end{array}$ & $\begin{array}{l}3.088^{* * *} \\
(1.085)\end{array}$ & $\begin{array}{c}2.841^{* * *} \\
(0.989)\end{array}$ \\
\hline Non-oil exports (percent of GDP) & $\begin{array}{l}0.148^{\star *} \\
(0.055)\end{array}$ & $\begin{array}{l}0.154^{\star *} \\
(0.060)\end{array}$ & $\begin{array}{l}0.148^{\star *} \\
(0.056)\end{array}$ & $\begin{array}{l}0.156^{\star *} \\
(0.059)\end{array}$ & $\begin{array}{l}0.149^{* *} \\
(0.056)\end{array}$ \\
\hline Reserve adequacy (percent of IMF metric) & $\begin{array}{c}0.007^{* * *} \\
(0.001)\end{array}$ & $\begin{array}{l}0.007^{\star * *} \\
(0.001)\end{array}$ & $\begin{array}{c}0.007^{\star * *} \\
(0.001)\end{array}$ & $\begin{array}{l}0.007^{* \star *} \\
(0.001)\end{array}$ & $\begin{array}{c}0.007^{* * *} \\
(0.001)\end{array}$ \\
\hline Inflation volatility (percent) & $\begin{array}{c}-1.655^{\star *} \\
(0.662)\end{array}$ & $\begin{array}{c}-1.537^{\star *} \\
(0.665)\end{array}$ & $\begin{array}{c}-1.531^{\star *} \\
(0.730)\end{array}$ & $\begin{array}{c}-1.541^{\star *} \\
(0.694)\end{array}$ & $\begin{array}{l}-1.503^{*} \\
(0.745)\end{array}$ \\
\hline Net government debt (percent of GDP) & $\begin{array}{c}-0.003^{* * *} \\
(0.000)\end{array}$ & & & & \\
\hline Net government debt (percent of non-oil revenue) & & $\begin{array}{c}-0.001^{* * *} \\
(0.000)\end{array}$ & & & \\
\hline Primary balance (percent of GDP) & & & $\begin{array}{c}0.109 \\
(0.086)\end{array}$ & & \\
\hline Primary balance (percent of non-oil revenue) & & & & $\begin{array}{l}0.009^{*} \\
(0.005)\end{array}$ & \\
\hline Overall balance (percent of GDP) & & & & & $\begin{array}{c}0.106 \\
(0.084)\end{array}$ \\
\hline Constant & $\begin{array}{c}-8.265^{\star * *} \\
(1.949)\end{array}$ & $\begin{array}{c}-8.510^{\star \star *} \\
(2.035)\end{array}$ & $\begin{array}{c}-8.590^{* * *} \\
(2.182)\end{array}$ & $\begin{array}{c}-8.582^{* * *} \\
(2.123)\end{array}$ & $\begin{array}{c}-8.485^{\text {** }} \\
(2.146)\end{array}$ \\
\hline $\begin{array}{l}\text { Observations } \\
\text { R-squared }\end{array}$ & $\begin{array}{c}26 \\
0.583 \\
\end{array}$ & $\begin{array}{c}26 \\
0.566 \\
\end{array}$ & $\begin{array}{c}26 \\
0.524 \\
\end{array}$ & $\begin{array}{c}26 \\
0.549 \\
\end{array}$ & $\begin{array}{c}26 \\
0.524 \\
\end{array}$ \\
\hline
\end{tabular}

Source: Authors' calculations.

Notes: Heteroskedasticity robust standard errors in parentheses; ${ }^{* *},{ }^{* *}$, and ${ }^{*}$ next to a number indicate statistical significance at 1,5 , and 10 percent, respectively.

value returns robust results. Regardless of whether 2011-13 or 2012-13 averages are used, the results are consistent with those of the baseline specification, as only inflation volatility loses significance in the broader samples. Overall, the results are supportive of the conclusions drawn with the baseline results. 
Table 4: Robustness Tests

\begin{tabular}{|c|c|c|c|c|c|c|c|c|c|c|c|c|c|c|c|}
\hline & \multicolumn{3}{|c|}{$\begin{array}{c}\text { Dependent variable: } \\
\text { Slowdown in real GDP growth } \\
(2015-16 \text { vs } 2011-14)\end{array}$} & \multicolumn{3}{|c|}{$\begin{array}{l}\text { Dependent variable: } \\
\text { wwdown in non-oil real GDP } \\
\text { owth (2015-16 vs 2011-14) }\end{array}$} & \multicolumn{3}{|c|}{$\begin{array}{c}\text { Dependent variable: } \\
\text { Percent deviation of actual } 2016 \\
\text { real GDP growth from Spring } 2014 \\
\text { WEO forecast } \\
\end{array}$} & \multicolumn{3}{|c|}{$\begin{array}{l}\text { Dependent variable: } \\
\text { Percent deviation of actual } 2016 \\
\text { real GDP growth from Fall } 2014 \\
\text { WEO forecast } \\
\end{array}$} & \multicolumn{3}{|c|}{$\begin{array}{c}\text { Dependent variable: } \\
\text { Percent deviation of actual } 2016 \\
\text { real GDP growth from Fall } 2014 \\
\text { WEO forecast } \\
\end{array}$} \\
\hline & $\begin{array}{c}(1) \\
\text { Core } \\
\text { sample } \\
\end{array}$ & $\begin{array}{c}(2) \\
\text { Heavily oil } \\
\text { dependent } \\
\end{array}$ & $\begin{array}{c}\text { (3) } \\
\text { All oil } \\
\text { exporters }\end{array}$ & $\begin{array}{c}(4) \\
\text { Core } \\
\text { sample }\end{array}$ & $\begin{array}{c}5) \\
\text { Heavily oil } \\
\text { dependent }\end{array}$ & $\begin{array}{c}6) \\
\text { All oil } \\
\text { exporters } \\
\end{array}$ & $\begin{array}{c}(7) \\
\text { Core } \\
\text { sample } \\
\end{array}$ & $\begin{array}{c}(8) \\
\text { Heavily oil } \\
\text { dependent } \\
\end{array}$ & $\begin{array}{c}(9) \\
\text { All oil } \\
\text { exporters }\end{array}$ & $\begin{array}{c}(10) \\
\text { Core } \\
\text { sample } \\
\end{array}$ & $\begin{array}{c}11) \\
\text { Heavily oil } \\
\text { dependent }\end{array}$ & $\begin{array}{c}(12) \\
\text { All oil } \\
\text { exporters } \\
\end{array}$ & $\begin{array}{c}(13) \\
\text { Core } \\
\text { sample } \\
\end{array}$ & $\begin{array}{c}(14) \\
\text { Heavily oil } \\
\text { dependent }\end{array}$ & $\begin{array}{c}(15) \\
\text { All oil } \\
\text { exporters } \\
\end{array}$ \\
\hline Exchange rate flexibility & $\begin{array}{c}0.792 \\
(0.574)\end{array}$ & $\begin{array}{l}1.597^{\star *} \\
(0.676)\end{array}$ & $\begin{array}{l}1.557^{\star *} \\
(0.630)\end{array}$ & $\begin{array}{l}1.796^{\star \star} \\
(0.781)\end{array}$ & $\begin{array}{l}2.486^{* \star *} \\
(0.732)\end{array}$ & $\begin{array}{c}2.543^{\star \star \star *} \\
(0.687)\end{array}$ & $\begin{array}{l}2.653^{* \star} \\
(1.057)\end{array}$ & $\begin{array}{l}4.162^{\star \star} \\
(1.540)\end{array}$ & $\begin{array}{l}3.414^{* *} \\
(1.405)\end{array}$ & $\begin{array}{l}2.290^{\star \star} \\
(1.077)\end{array}$ & $\begin{array}{l}4.615^{\star * \star} \\
(1.528)\end{array}$ & $\begin{array}{l}4.360^{\star \star \star} \\
(1.465)\end{array}$ & $\begin{array}{l}2.512^{\star \star} \\
(1.022)\end{array}$ & $\begin{array}{c}4.442^{\star \star \star} \\
(1.413)\end{array}$ & $\begin{array}{l}4.274^{\star \star \star} \\
(1.401)\end{array}$ \\
\hline Non-oil exports (percent of GDP) 1/2/3/ & $\begin{array}{l}0.053^{* *} \\
(0.024)\end{array}$ & $\begin{array}{l}0.078^{\star *} \\
(0.028)\end{array}$ & $\begin{array}{l}0.076^{* \star *} \\
(0.024)\end{array}$ & $\begin{array}{l}0.095^{\star \star} \\
(0.043)\end{array}$ & $\begin{array}{l}0.131^{* \star *} \\
(0.039)\end{array}$ & $\begin{array}{l}0.124^{\star \star \star} \\
(0.031)\end{array}$ & $\begin{array}{l}0.169^{* * *} \\
(0.046)\end{array}$ & $\begin{array}{l}0.174^{* \star \star} \\
(0.050)\end{array}$ & $\begin{array}{l}0.204^{* \star *} \\
(0.055)\end{array}$ & $\begin{array}{l}0.155^{\star \star \star} \\
(0.045)\end{array}$ & $\begin{array}{l}0.171^{\star *} \\
(0.064)\end{array}$ & $\begin{array}{l}0.1811^{* \star \star} \\
(0.051)\end{array}$ & $\begin{array}{l}0.168^{* \star \star} \\
(0.044)\end{array}$ & $\begin{array}{l}0.180^{* * *} \\
(0.062)\end{array}$ & $\begin{array}{l}0.185^{* \star *} \\
(0.050)\end{array}$ \\
\hline Reserve adequacy (percent of IMF metric) 2/3/ & $\begin{array}{l}0.003^{* * *} \\
(0.001)\end{array}$ & $\begin{array}{l}0.004^{\star \star} \\
(0.002)\end{array}$ & $\begin{array}{l}0.003^{* *} \\
(0.001)\end{array}$ & $\begin{array}{l}0.004^{* \star *} \\
(0.001)\end{array}$ & $\begin{array}{l}0.004^{* * *} \\
(0.001)\end{array}$ & $\begin{array}{l}0.003^{* *} \\
(0.001)\end{array}$ & $\begin{array}{l}0.007^{\star \star \star} \\
(0.001)\end{array}$ & $\begin{array}{l}0.010^{\star \star \star \star} \\
(0.003)\end{array}$ & $\begin{array}{l}0.008^{\star *} \\
(0.003)\end{array}$ & $\begin{array}{l}0.007^{\star * *} \\
(0.001)\end{array}$ & $\begin{array}{l}0.010^{* * *} \\
(0.003)\end{array}$ & $\begin{array}{l}0.007^{* * *} \\
(0.002)\end{array}$ & $\begin{array}{l}0.007^{\star * *} \\
(0.001)\end{array}$ & $\begin{array}{l}0.010^{* \star *} \\
(0.004)\end{array}$ & $\begin{array}{l}0.008^{* \star *} \\
(0.003)\end{array}$ \\
\hline Inflation & $\begin{array}{c}-1.065^{\star \star \star} \\
(0.364)\end{array}$ & $\begin{array}{l}0.357^{\star} \\
(0.189)\end{array}$ & $\begin{array}{l}0.373^{* \star} \\
(0.137)\end{array}$ & $\begin{array}{l}-0.873 \\
(0.618)\end{array}$ & $\begin{array}{c}0.261 \\
(0.170)\end{array}$ & $\begin{array}{l}0.288^{* *} \\
(0.123)\end{array}$ & $\begin{array}{c}-1.907^{\star \star \star} \\
(0.555)\end{array}$ & $\begin{array}{c}-1.767^{* * *} \\
(0.146)\end{array}$ & $\begin{array}{l}-1.475^{* \star *} \\
(0.314)\end{array}$ & $\begin{array}{l}-1.139^{\star} \\
(0.657)\end{array}$ & $\begin{array}{c}0.654 \\
(0.969)\end{array}$ & $\begin{array}{c}0.684 \\
(0.753)\end{array}$ & $\begin{array}{l}-1.086 \\
(0.631)\end{array}$ & $\begin{array}{c}0.530 \\
(1.036)\end{array}$ & $\begin{array}{c}0.644 \\
(0.736)\end{array}$ \\
\hline Net government debt (percent of revenue) 2/3/ & $\begin{array}{l}-0.000^{*} \\
(0.000)\end{array}$ & $\begin{array}{l}-0.001^{*} \\
(0.000)\end{array}$ & $\begin{array}{l}-0.001 \\
(0.000)\end{array}$ & $\begin{array}{c}-0.001^{\star \star \star *} \\
(0.000)\end{array}$ & $\begin{array}{c}-0.001^{* \star *} \\
(0.000)\end{array}$ & $\begin{array}{c}-0.001^{\star \star * *} \\
(0.000)\end{array}$ & $\begin{array}{c}-0.001^{\star \star \star \star} \\
(0.000)\end{array}$ & $\begin{array}{c}-0.002^{\star * *} \\
(0.001)\end{array}$ & $\begin{array}{l}-0.001 \\
(0.001)\end{array}$ & $\begin{array}{c}-0.006^{* \star *} \\
(0.001)\end{array}$ & $\begin{array}{c}-0.008^{\star \star \star} \\
(0.003)\end{array}$ & $\begin{array}{l}-0.005^{\star} \\
(0.003)\end{array}$ & $\begin{array}{c}-0.004^{* \star *} \\
(0.001)\end{array}$ & $\begin{array}{c}-0.006^{* * *} \\
(0.002)\end{array}$ & $\begin{array}{c}-0.004^{\star *} \\
(0.002)\end{array}$ \\
\hline Constant & $\begin{array}{l}-3.044^{* *} \\
(1.087)\end{array}$ & $\begin{array}{c}-5.653^{* \star *} \\
(1.187)\end{array}$ & $\begin{array}{c}-4.952^{\star \star *} \\
(1.084)\end{array}$ & $\begin{array}{l}-5.462^{* *} \\
(2.053)\end{array}$ & $\begin{array}{c}-8.055^{* * *} \\
(1.371)\end{array}$ & $\begin{array}{c}-6.955^{* \star *} \\
(1.297)\end{array}$ & $\begin{array}{c}-9.1115^{* * *} \\
(1.898)\end{array}$ & $\begin{array}{c}-9.431^{\star * \star *} \\
(1.878)\end{array}$ & $\begin{array}{c}-9.347^{* * *} \\
(2.272)\end{array}$ & $\begin{array}{c}-8.076^{* \star *} \\
(2.079)\end{array}$ & $\begin{array}{c}-13.320^{* * *} \\
(3.242)\end{array}$ & $\begin{array}{c}-11.972^{* * * *} \\
(2.542)\end{array}$ & $\begin{array}{c}-8.380^{* * *} \\
(1.981)\end{array}$ & $\begin{array}{c}-13.295^{* * *} \\
(3.241)\end{array}$ & $\begin{array}{c}-12.155^{* * *} \\
(2.530)\end{array}$ \\
\hline $\begin{array}{l}\text { Observations } \\
\text { R-squared }\end{array}$ & $\begin{array}{c}26 \\
0.529\end{array}$ & $\begin{array}{c}30 \\
0.261\end{array}$ & $\begin{array}{c}42 \\
0.248\end{array}$ & $\begin{array}{c}26 \\
0.440\end{array}$ & $\begin{array}{c}30 \\
0.372\end{array}$ & $\begin{array}{c}42 \\
0.367\end{array}$ & $\begin{array}{c}26 \\
0.661\end{array}$ & $\begin{array}{c}30 \\
0.676\end{array}$ & $\begin{array}{c}42 \\
0.552\end{array}$ & $\begin{array}{c}26 \\
0.557\end{array}$ & $\begin{array}{c}29 \\
0.281\end{array}$ & $\begin{array}{c}41 \\
0.243\end{array}$ & $\begin{array}{c}26 \\
0.564\end{array}$ & $\begin{array}{c}29 \\
0.279\end{array}$ & $\begin{array}{c}41 \\
0.249\end{array}$ \\
\hline
\end{tabular}

Source: Authors' calculations.

Notes: Heteroskedasticity robust standard errors in parentheses; ***,**, and * next to a number indicate statistical significance at 1,5 , and 10 percent, respec-

tively. 1/ The variable used in columns 7 to 9 was measured in Spring 2014. 2/ The variable used in columns 10 to 12 is an average of the 2011-13 values. 3/

The variable used in columns 13 to 15 is an average of the 2012-13 values. 


\subsection{Extensions}

To test the importance of other factors that may affect the severity of the impact of falling oil prices, we extend the baseline specification to additional variables, focusing on the core sample of countries. ${ }^{23}$ Table 5 reports the results for several variables, while the results using other regressors are available upon request.

With respect to the macroeconomic policy space, we include the output gap and inflation rate. To control for external factors, we add the change in a terms of trade indicator over 2013-16, the REER overvaluation, trading partners' real GDP growth relative to the Fall 2014 forecast, and net foreign assets. ${ }^{24}$ Oil dependence and economic diversification are controlled for by including oil exports, oil revenue, the non-oil terms of trade relative to the Fall 2014 forecast, and the non-oil current account balance. ${ }^{25}$ Finally, structural flexibility is proxied by the overall governance indicator and the overall Doing Business indicator from the World Bank, while financial development is proxied by the stock of private credit, and its flow (measured as the change, relative to GDP, in the three years before the oil shock). ${ }^{26}$

In some cases, trade-offs between the variables included in the baseline specification could exist. For example, while the impact of the shock was higher for countries running a fixed or fullydollarized exchange rate regime, such a regime may serve as an effective nominal anchor, imparting price stability and reducing the impact. Furthermore, countries may have accumulated larger fiscal and external buffers to provide the needed backing for the fixed regime. Conversely, countries that are less dependent on oil could whether the impact of the price shock with more limited buffers. We try several interaction variables exploring these effects, but none returns significant coefficients. $^{27}$

The results suggest that none of the additional variables has a significant effect on the severity of the shocks' impact. Furthermore, in almost all cases the baseline regressors preserve their significance and the magnitude of their coefficients. Similarly, the share of variance explained by the baseline regressors plus the additional one ranges between 58 and 62 percent across all regressions, indicating these variables add little additional explanatory power compared to the baseline regression.

\footnotetext{
${ }^{23}$ While it may be desirable to include more than one variable at a time in some cases, we refrain from doing that due to the small number of observations.

${ }^{24}$ We rely on the terms of trade shock measure used in Adler and Magud (2015). However, we take the difference between the actual terms of trade change and the forecast as of Fall 2014.

${ }^{25}$ Variables entering as a share of GDP were also tested as a share of exports, revenue, etc., and results were the same.

${ }^{26}$ Other indicators, including the Economic Complexity Index, the Economic Freedom of the World index (and its subindicators for Area 2, 4, and 5), and the Global Competitiveness Index for Pillar 1, 6, 7, 8, and 9), return insignificant results and in some cases decrease the already low number of observations.

${ }^{27}$ Results are available upon request.
} 
Table 5: Extensions

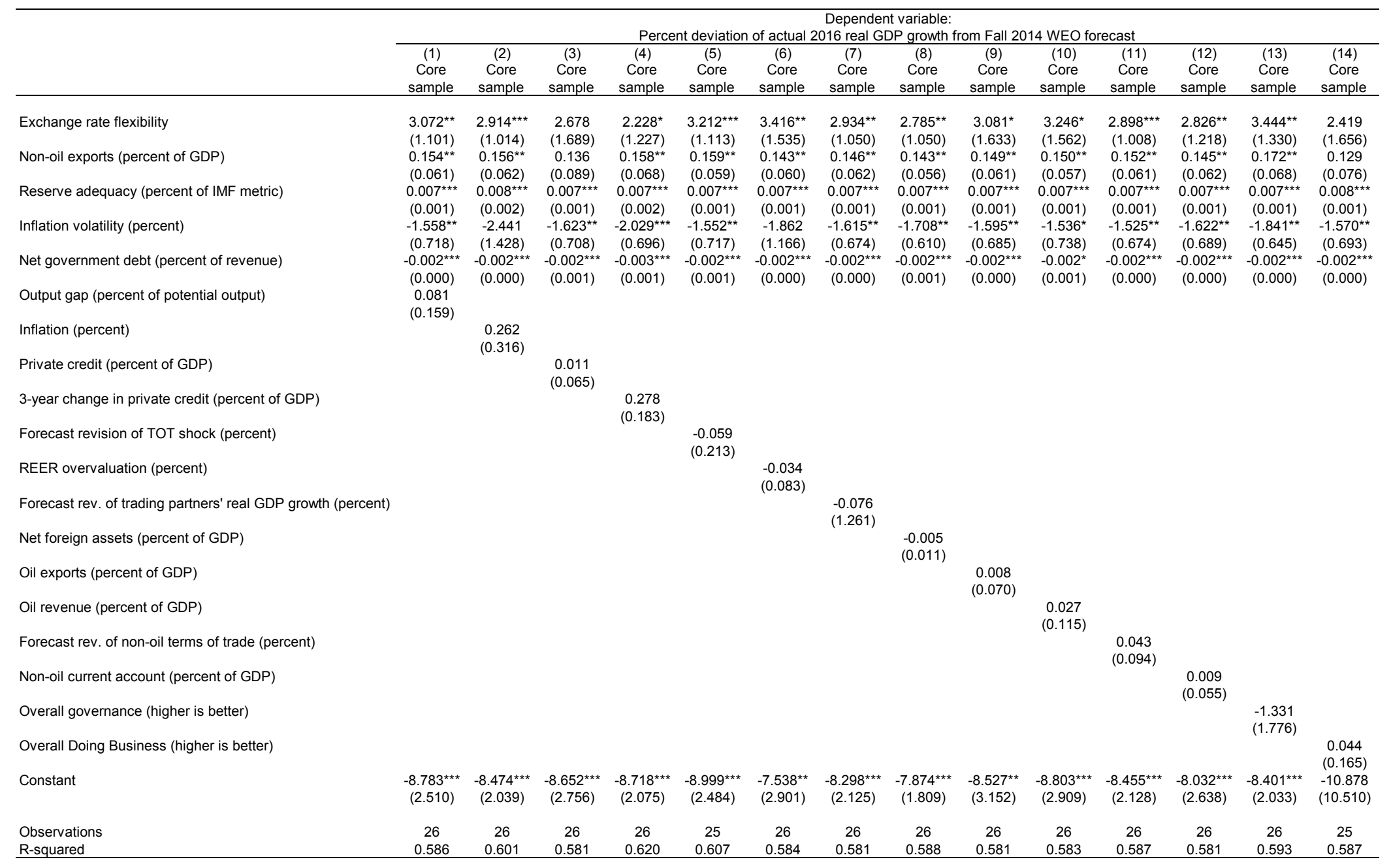

Source: Authors' calculations.

Notes: Heteroskedasticity robust standard errors in parentheses; ${ }^{* *},{ }^{* *}$, and ${ }^{*}$ next to a number indicate statistical significance at 1,5 , and 10 percent, respectively. 


\section{Conclusions}

The decline in oil prices in 2014-16 was one of the sharpest in history, and put to test the resilience of oil exporters. Unsurprisingly, many countries suffered a significant slowdown in economic activity that caused large deviations of real GDP growth in 2015 and 2016 relative to forecasts made before the shock. However, some countries weathered the negative supply shock induced by the fall in oil prices far better than others, reflecting stronger initial conditions and fundamentals. Perhaps surprisingly, the degree of oil dependence was not a significant determinant of the impact of the shock.

This paper investigates the factors that helped oil exporters soften the severity of the consequences of the 2014-16 oil price decline and draws some policy lessons. We find that countries with more macroeconomic policy space (fiscal and monetary) weathered the shock better, suggesting either that these countries were able to engage in counter-cyclical policies, or strong fundamentals supported confidence, buffering the impact on consumption and investment. Also, countries with a flexible exchange rate regime were less impact than those with a fixed regime, pointing to the role of the exchange rate in buffering the slowdown in the real economy by letting relative prices absorb, at least in part, the burden of the adjustment, or through providing fiscal space by raising revenue in terms of domestic currency. Economies with more diversified export bases also proved more resilient, underscoring the importance of having multiple sources of foreign exchange earnings. Finally, the shock's impact was lower in countries with more adequate reserve buffers, suggesting they contributed to soften the magnitude of the shock's impact. Together, these factors explain a large share of the deviation of real GDP growth outturns from forecasts. Looking forward, policy efforts aimed at building or restoring the conditions that helped dampen the negative effects of the 2014-16 oil price shock are necessary. 


\section{References}

Adler, Gustavo and Nicolas E Magud (2015). "Four Decades of Terms-of-Trade Booms: A Metric of Income Windfall". In: Journal of International Money and Finance 55, pp. 162-192.

Anzuini, Alessio, Patrizio Pagano, and Massimiliano Pisani (2015). "Macroeconomic Effects of Precautionary Demand for Oil". In: Journal of Applied Econometrics 30.6, pp. 968-986.

Berkmen, S. Pelin, Gaston Gelos, Robert Rennhack, and James P. Walsh (2012). "The Global Financial Crisis: Explaining the Cross-Country Differences in the Output Impact". In: Journal of International Money and Finance 31.1, pp. 42-59.

Bernanke, Ben S (1983). "Irreversibility, Uncertainty, and Cyclical Investment". In: The Quarterly Journal of Economics 98.1, pp. 85-106.

Berument, M Hakan, Nildag Basak Ceylan, and Nukhet Dogan (2010). "The Impact of Oil Price Shocks on the Economic Growth of Selected MENA Countries". In: The Energy Journal, pp. 149176.

Blanchard, Olivier J., Hamid Faruqee, and Mitali Das (2010). "The Initial Impact of the Crisis on Emerging Market Countries". In: Brookings Papers on Economic Activity Spring, pp. 263-323.

Cashin, Paul, Kamiar Mohaddes, Maziar Raissi, and Mehdi Raissi (2014). "The Differential Effects of Oil Demand and Supply Shocks on the Global Economy". In: Energy Economics 44, pp. $113-134$.

Cerdeiro, Diego A. and Dmitry Plotnikov (2017). "Taking Stock: Who Benefited from the Oil Price Shocks?" In: IMF Working Paper WP/17/104.

Cespedes, Luis F. and Andres Velasco (2012). "Macroeconomic Performance During Commodity Price Booms and Busts". In: IMF Economic Review 60.4, pp. 570-599.

Claesens, Stijn, Giovanni Dell'Ariccia, Deniz Igan, and Luc Laeven (2010). "Cross-country Experiences and Policy Implications from the Global Financial Crisis". In: Economic Policy 62.April, pp. 267-293.

De Gregorio, José (2012). "Commodity Prices, Monetary Policy, and Inflation". In: IMF Economic Review 60.4, pp. 600-633.

Frankel, Jeffrey A (2005). "Peg the Export Price Index: A Proposed Monetary Regime for Small Countries". In: Journal of Policy Modeling 27.4, pp. 495-508.

Friedman, Milton (1966). "Flexible Exchange Rates". In: Essays in Positive Economics.

IMF (2015a). "Learning to Live with Cheaper Oil Amid Weaker Demand". In: IMF Regional Economic Outlook Update, Middle east and Central Asia.

- (2015b). "The Commodities Roller Coaster. A Fiscal Framework for Uncertain Times". In: IMF Fiscal Monitor.

- (2015c). "Where are Commodity Exporters Headed? Output Growth in the Aftermath of the Commodity Boom". In: IMF World Economic Outlook, Chapter 2.

Jiménez-Rodríguez, Rebeca and Marcelo Sánchez (2005). "Oil price shocks and real GDP growth: empirical evidence for some OECD countries". In: Applied Economics 37.2, pp. 201-228.

Kilian, Lutz (2009). "Not All Oil Price Shocks Are Alike: Disentangling Demand and Supply Shocks in the Crude Oil Market". In: American Economic Review 99.3, pp. 1053-1069.

- (2014). "Oil Price Shocks: Causes and Consequences". In: Annual Review of Resource Econonomics 6.1 , pp. $133-154$.

Lane, Philip R. and Gian Maria Milesi-Ferretti (2010). "The Cross-Country Incidence of the Global Crisis". In: IMF Economic Review 59.1, pp. 77-110.

Lundgren, Charlotte J., Alun H.Thomas, and Robert C. York (2013). "Boom, Bust, or Prosperity? Managing Sub-Saharan Africa's Natural Resource Wealth". In: IMF publications.

Mohaddes, Kamiar and M. Hashem Pesaran (2015). "Country-Specific Oil Supply Shocks and the Global Economy: A Counterfactual Analysis". In: Federal Reserve Bank of Dallas Globalization and Monetary Policy Institute Working Paper No. 242. 
Pindyck, Robert S et al. (1991). "Irreversibility, Uncertainty, and Investment". In: Journal of Economic Literature 29.3, pp. 1110-48.

Rose, Andrew K. and Mark M. Spiegel (2011). "Cross-Country Causes and Consequences of the Crisis: An Update". In: European Economic Review 55.3, pp. 309-324.

Setser, Brad et al. (2007). The Case for Exchange Rate Flexibility in Oil-Exporting Economies. Tech. rep. Peterson Institute for International Economics.

Spatafora, Nikola and Irina Tytell (2012). "Commodity Terms of Trade: The History of Booms and Busts". In: IMF Working Paper WP/09/205.

Svirydzenka, Katsiaryna (2016). "Introducing a New Broad-Based Index of Financial Development". In: IMF Working Paper WP/16/5.

Tsangarides, Charalambos G. (2012). "Crisis and Recovery: Role of the Exchange Rate Regime in Emerging Market Economies". In: Journal of Macroeconomics 34.2, pp. 470-488.

Van der Ploeg, Frederick and Steven Poelhekke (2009). "Volatility and the Natural Resource Curse". In: Oxford Economic Papers. 


\section{Appendix A. Country Groups}

Core sample: Algeria, Angola, Azerbaijan, Bahrain, Brunei Darussalam, Cameroon, Chad, Colombia, Congo (Republic of), Ecuador, Equatorial Guinea, Gabon, Kazakhstan, Kuwait, Malaysia, Nigeria, Norway, Oman, Qatar, Russia, Saudi Arabia, Timor-Leste, Trinidad and Tobago, Turkmenistan, United Arab Emirates, Venezuela.

Heavily oil dependent: Algeria, Angola, Azerbaijan, Bahrain, Brunei Darussalam, Cameroon, Chad, Colombia, Congo (Republic of), Ecuador, Equatorial Guinea, Gabon, Iran, Iraq, Kazakhstan, Kuwait, Malaysia, Nigeria, Norway, Oman, Qatar, Russia, Saudi Arabia, South Sudan, Timor-Leste, Trinidad and Tobago, Turkmenistan, United Arab Emirates, Venezuela, Yemen.

All oil exporters: Algeria, Angola, Argentina, Australia, Azerbaijan, Bahrain, Brazil, Brunei Darussalam, Cameroon, Canada, Chad, Colombia, Congo (Republic of), Denmark, Ecuador, Egypt, Equatorial Guinea, Gabon, Indonesia, Iran, Iraq, Kazakhstan, Kuwait, Malaysia, Mexico, Nigeria, Norway, Oman, Qatar, Russia, Saudi Arabia, South Sudan, Sudan, Timor-Leste, Trinidad and Tobago, Tunisia, Turkmenistan, United Arab Emirates, United Kingdom, Venezuela, Vietnam, Yemen. 


\section{Appendix B. Data}

Table B.1 lists all variables used in the paper, along with the source and the construction details:

Table B.1: Data Sources and Definitions

\begin{tabular}{|c|c|c|}
\hline \\
\hline & Dependent variables & \multirow{4}{*}{$\begin{array}{l}\text { Actual real GDP growth in } 2016 \text { minus forecast in Fall } 2014 \\
\text { or Spring } 2014 \\
\text { Growth rate of real GDP growth in 2015-2016 minus } \\
\text { compound growth rate of real GDP growth in 2011-14 } \\
\text { Growth rate of non-oil real GDP growth in 2015-2016 minus } \\
\text { compound growth rate of non-oil real GDP growth in 2011- } \\
14\end{array}$} \\
\hline \multirow{3}{*}{$\begin{array}{l}\text { Deviation of actual } 2016 \text { real GDP } \\
\text { growth from WEO forecast (percent) } \\
\text { Slowdown in real GDP growth 2015-16 } \\
\text { vs 2011-14 (percent) } \\
\text { Slowdown in non-oil real GDP growth } \\
2015-16 \text { vs 2011-14 (percent) } \\
\end{array}$} & World Economic Outlook & \\
\hline & World Economic Outlook & \\
\hline & World Economic Outlook & \\
\hline \multicolumn{3}{|l|}{ Baseline regressors } \\
\hline Exchange rate flexibility & $\begin{array}{l}\text { IMF's Annual Report on Exchange } \\
\text { Arrangements and Exchange } \\
\text { Restrictions }\end{array}$ & \multirow{2}{*}{$\begin{array}{l}2013 \text { value, one if floating regimes, negative one if } \\
\text { stabilized arrangements, conventional pegs, currency } \\
\text { boards, and officially-dollarized regimes, and zero if other } \\
\text { arrangements } \\
2013 \text {, average } 2011-13 \text {, or average 2012-13 value of non- } \\
\text { oil exports as a share of GDP }\end{array}$} \\
\hline Non-oil exports (percent of GDP) & $\begin{array}{l}\text { World Economic Outlook and IMF's } \\
\text { Article IV Staff Reports }\end{array}$ & \\
\hline $\begin{array}{l}\text { Reserve adequacy (percent of IMF } \\
\text { metric) }\end{array}$ & $\begin{array}{l}\text { World Economic Outlook and IMF's } \\
\text { Article IV Staff Reports }\end{array}$ & $\begin{array}{l}\text { 2013, average 2011-13, or average } 2012-13 \text { value of } \\
\text { reserves assets as a share of the IMF metric, defined as } 20 \\
\text { (15) percent of portfolio and other investment liabilities, } 10 \\
\text { (5) percent of broad money, and } 10 \text { (5) percent of exports } \\
\text { for economies with fixed (flexible) exchange rate regimes }\end{array}$ \\
\hline Inflation volatility (percent) & World Economic Outlook & \multirow{2}{*}{$\begin{array}{l}2013 \text {, average } 2011-13 \text {, or average } 2012-13 \text { value of 3- } \\
\text { year standard deviation of the percent change in CPI } \\
2013 \text {, average } 2011-13 \text {, or average } 2012-13 \text { value of gross } \\
\text { debt minus gross assets as a share of revenue }\end{array}$} \\
\hline $\begin{array}{l}\text { Net government debt (percent of } \\
\text { revenue) }\end{array}$ & $\begin{array}{l}\text { World Economic Outlook and External } \\
\text { Wealth of Nations Database }\end{array}$ & \\
\hline \multicolumn{3}{|l|}{ Alternative fiscal variables } \\
\hline \multirow{6}{*}{$\begin{array}{l}\text { Net government debt (percent of GDP) } \\
\text { Net government debt (percent of non-oil } \\
\text { revenue) } \\
\text { Primary balance (percent of GDP) } \\
\text { Primary balance (percent of revenue) } \\
\text { Primary balance (percent of non-oil } \\
\text { revenue) } \\
\text { Overall balance (percent of GDP) } \\
\end{array}$} & $\begin{array}{l}\text { World Economic Outlook and External } \\
\text { Wealth of Nations Database }\end{array}$ & \multirow{6}{*}{$\begin{array}{l}2013 \text { value of gross debt minus gross assets as a sha } \\
\text { GDP } \\
2013 \text { value of gross debt minus gross assets as a sha } \\
\text { non-oil revenue } \\
2013 \text { value of primary balance as a share of GDP } \\
2013 \text { value of primary balance as a share of revenue } \\
2013 \text { value of primary balance as a share of non-oil } \\
\text { revenue } \\
2013 \text { value of overall balance as a share of GDP }\end{array}$} \\
\hline & $\begin{array}{l}\text { World Economic Outlook and External } \\
\text { Wealth of Nations Database }\end{array}$ & \\
\hline & & \\
\hline & World Economic Outlook & \\
\hline & World Economic Outlook & \\
\hline & World Economic Outlook & \\
\hline \multicolumn{3}{|l|}{ tensior } \\
\hline tensio & \multirow{2}{*}{$\begin{array}{l}\text { World Economic Outlook } \\
\text { World Economic Outlook and World } \\
\text { Development Indicators }\end{array}$} & 2013 value of percent change in CPI \\
\hline Private credit (percent of GDP) & & 2013 value of stock of private credit as a share of GDP \\
\hline $\begin{array}{l}\text { 3-year change in private credit (percent } \\
\text { of GDP) }\end{array}$ & $\begin{array}{l}\text { World Economic Outlook and World } \\
\text { Development Indicators }\end{array}$ & $\begin{array}{l}2013 \text { value of 3-year change in the stock of private credit } \\
\text { as a share of GDP }\end{array}$ \\
\hline Forecast revision of TOT shock (percent) & World Economic Outlook & $\begin{array}{l}\text { Actual TOT shock over 2013-16 minus forecast TOT minus } \\
\text { forecast in Fall } 2014 \text { (see Adler and Magud, 2015) }\end{array}$ \\
\hline REER overvaluation ( & Inform & $\begin{array}{l}2013 \text { percent deviation of observed REER from its 3-year } \\
\text { average }\end{array}$ \\
\hline $\begin{array}{l}\text { Forecast revision of trading partners' real } \\
\text { GDP growth (percent) }\end{array}$ & World Economic Outlook & $\begin{array}{l}\text { Actual trading partners' real GDP growth in } 2016 \text { minus } \\
\text { forecast in Fall } 2014\end{array}$ \\
\hline Net foreign assets (percent of GDP) & $\begin{array}{l}\text { World Economic Outlook and External } \\
\text { Wealth of Nations Database }\end{array}$ & 2013 value of foreign assets minus foreign liabilities \\
\hline Oil exports (percent of GDP) & $\begin{array}{l}\text { World Economic Outlook and IMF's } \\
\text { Article IV Staff Reports }\end{array}$ & 2013 value of oil exports as a share of GDP \\
\hline Oil revenue (percent of GDP) & $\begin{array}{l}\text { World Economic Outlook and IMF's } \\
\text { Article IV Staff Reports }\end{array}$ & 2013 value o \\
\hline $\begin{array}{l}\text { Forecast revision of non-oil terms of } \\
\text { trade }\end{array}$ & World Economic Outlook & $\begin{array}{l}\text { Actual non-oil terms of trade in } 2016 \text { minus forecast in Fall } \\
2014\end{array}$ \\
\hline Non-oil current account (percent of GDP) & World Economic Outlook & 2013 value of non-oil current account as a share of GDP \\
\hline Overall governance (higher is better) & Worldwide Governance Indicators & 2013 value of overall governance indicator from 1 to 6 \\
\hline Overall Doing Business (higher is better) & Doing Business & 2013 value of overall Doing Business indicator from 1 to 6 \\
\hline
\end{tabular}

\section{CInternational Monetary Fund. Not for Redistribution}

